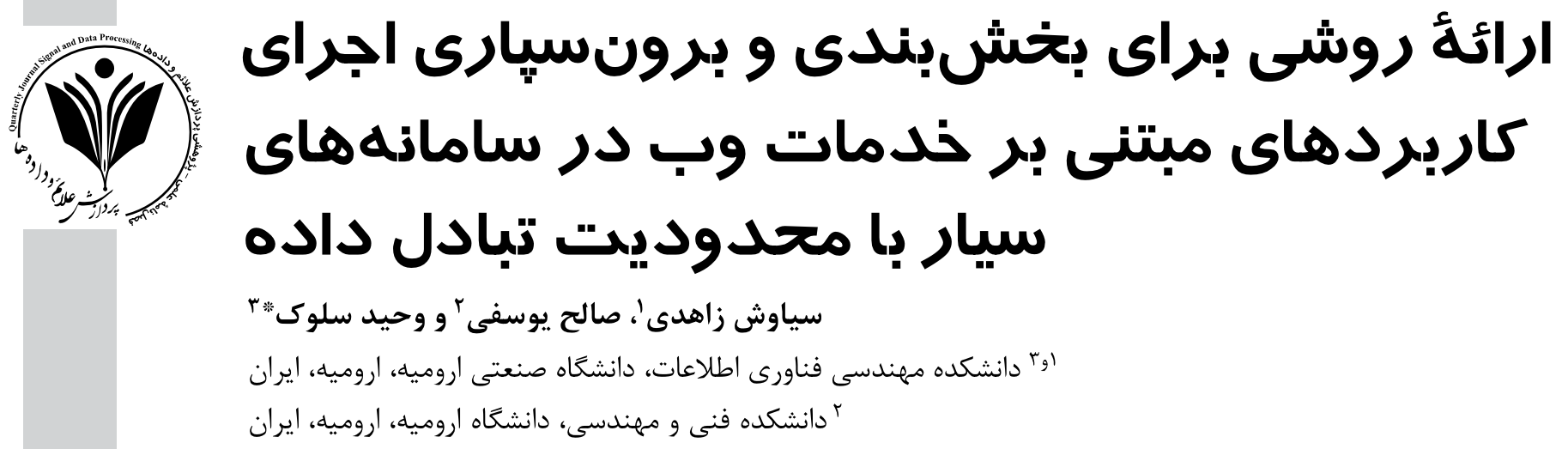

جكنيده

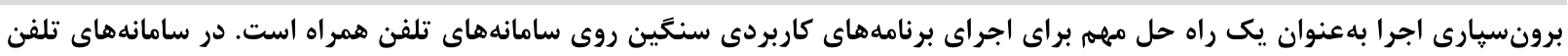

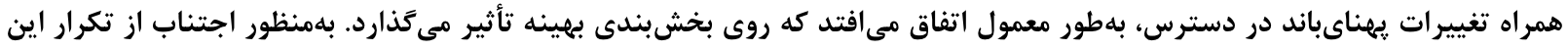

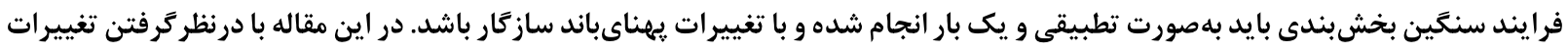

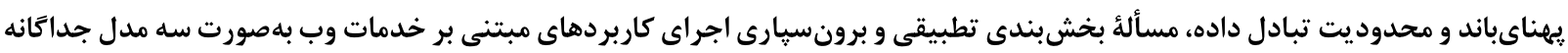

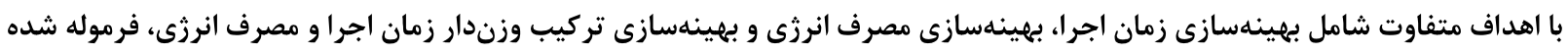

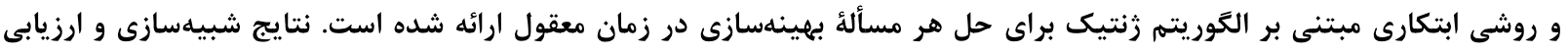

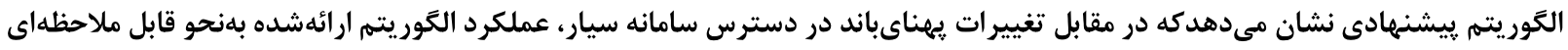
بهتر از كارهاى مشابه است. وازٔكان كليدى: برونسيارى اجرا، بخشبندى، تطبيق با يِهناىباند، خدمات وب، محدوديت تبادل داده.

\title{
Design and Evaluation of a Method for Partitioning and Offloading Web-based Applications in Mobile Systems with Bandwidth Constraints
}

\author{
Siawash Zahedi ${ }^{1}$, Saleh Yousefi ${ }^{2}$ \& Vahid Solouk ${ }^{* 3}$ \\ ${ }^{1,3}$ Faculty of IT and Computer Engineering, Urmia University of Technology, Urmia, Iran \\ ${ }^{2}$ Faculty of Engineering, Urmia University, Urmia, Iran
}

\begin{abstract}
Computation offloading is known to be among the effective solutions of running heavy applications on smart mobile devices. However, irregular changes of a mobile data rate have direct impacts on code partitioning when offloading is in progress. It is believed that once a rate-adaptive partitioning performed, the replication of such substantial processes due to bandwidth fluctuation can be avoided. Currently, a wide range of mobile applications are based on web services, which in turn influences the process of offloading and partitioning. As a result, mobile users are prone to face difficulties in data communications due to cost of preferences or connection quality. Taking into account the fluctuations of mobile connection bandwidth and thereby data rate constraints, the current paper proposes a method of adaptive partitioning and computation offloading in three forms. Accordingly, an optimization problem is primarily formulated to each of three main objectives under the investigation. These objectives include run time, energy consumption and the weighted composition of run time and energy consumption. Next, taking into consideration the time complexity of the optimization problems, a heuristic partitioning method based on Genetic Algorithm (GABP) is proposed to solve each of
\end{abstract}

* Corresponding author

* *ويسنده عهدهدار مكاتبات

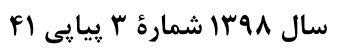


the three objectives and with the capability of acceptable performance maintenance in both dynamic and static partitionings. In order to evaluate and analyze the performance of the proposed approach, a simulation framework was built to run for random graphs of different sizes with the capability of setting specific bandwidth limits as target. The simulation results evidence improved performance against bandwidth fluctuations when compared to similar approaches. Moreover, it was also seen that once the problem circumstances are modified, the offloading can take place in the vicinity of the target node. Furthermore, we implemented the proposed method in form of an application on Android platform to conduct experiments on real applications. The experiments prove that those partitions of the applications requiring higher processing reqources rather than data rate are the best candidates for offloading.

Keywords: Computation offloading, partitioning, bandwidth adaptation, web service, data rate limitation

برنامهاى كاربردى امكانيذير نباشد؛ بنابراين براى بهبود

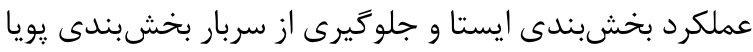
بخشبندى تطبيقى با يهناىباند مطرح مىشود. در اين حالت

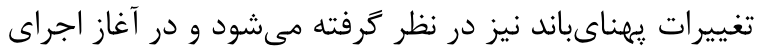
برنامه بخشبندى بلصورتى انتخاب شود كه در صورت كاهش

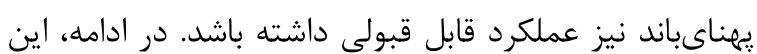

$$
\text { موضوع با يك مثال نشان داده شده است. }
$$

(جدول -1): زماناجراى برنامهى كاربردى نمونه در شكل (1) در

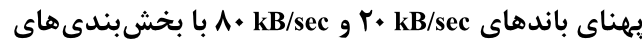
محاسبdشده

(Table-1): Sample Application Runtimes of Fig. 1 using

\begin{tabular}{|c|c|c|}
\hline \multicolumn{3}{|r|}{ Partitioning } \\
\hline $\begin{array}{c}\mathrm{kB} / \mathrm{sec} \\
\Lambda .\end{array}$ & $\begin{array}{c}\mathbf{k B} / \mathbf{s e c} \\
r .\end{array}$ & \\
\hline rAN/TD & FTD & 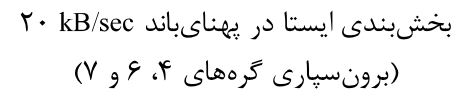 \\
\hline$r V V / r$ & $99 \mathrm{~V} / \mathrm{T}$ & 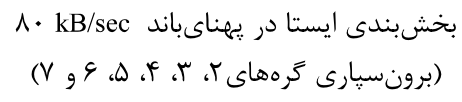 \\
\hline 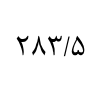 & FAS & 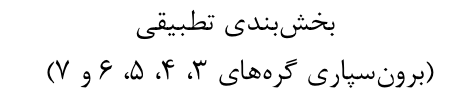 \\
\hline
\end{tabular}

در شكل (1) نحوهُ نمايش يك برنامة كاربردى نمونه با

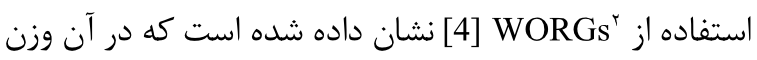

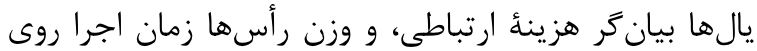

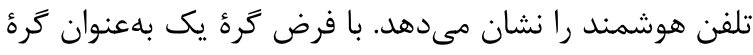
محلى و سرعت سرور ينج برابر سرعت تلفن هوشمند، سه نوع رهن

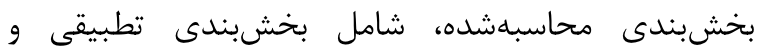

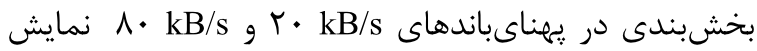
داده شده است. در جدول (1) زماناجراى برنامهى كاربردى

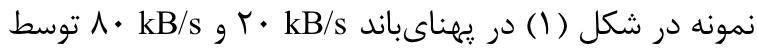
بخشبندىهاى محاسبهشده، نشان داده شده است. جدول (1) نشان مىدهد كه در صورت تغيير يهناىبند، روش ايستا

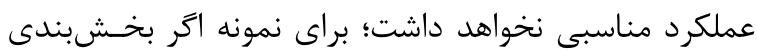

\footnotetext{
${ }^{2}$ Weighted object relation graph
}

\section{هol -}

برنامههاى كاربردى تلفن همراه بهطور جشمى جيرى فراخير

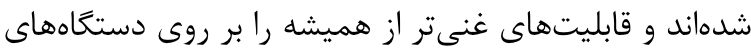

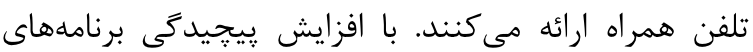
كاربردى، نياز آنها به منابع محاسباتى نيز افزايش ريّا

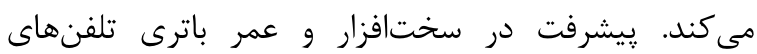
هوشمند در قاسخ گُويى به افزايش خواستههاى محاسباتى

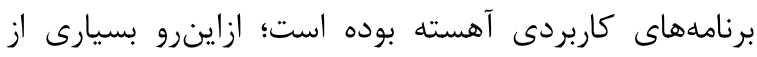
برنامههاى كاربردى بهدليل محدوديتهاى توان محاسباتى و

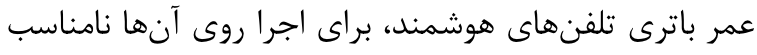

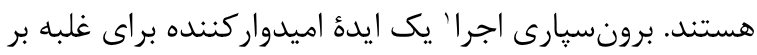

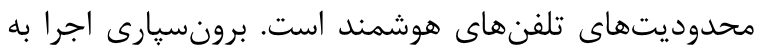

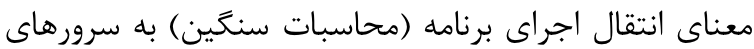
قدرتمند و دريافت نتايج از آنها است [3-1-1].

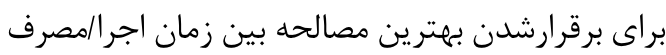

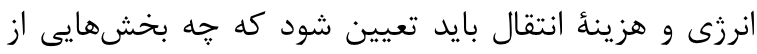

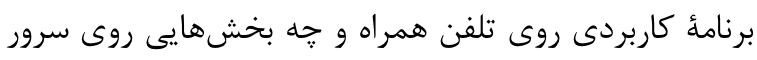
اجرا شود، كه اين كار بخشبندى ناميده مى شود [1,4]. بهطور شهودى مىتوان كفت اجزايى از برنامة كاربردى براى برونسيارى مناسبند كه نيازمند محاسبات زياد و هزئ هزئه ارتباطى كمى هستند [5]. بخشبندى بهصورت يويا و ايستا

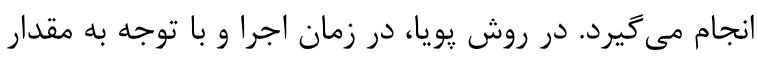

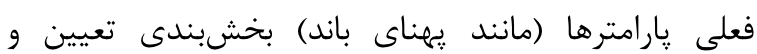

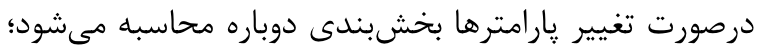

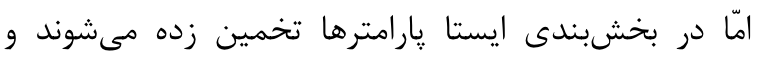

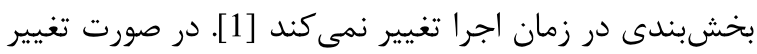

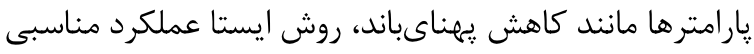

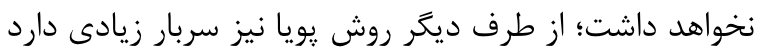

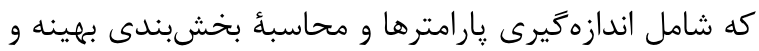

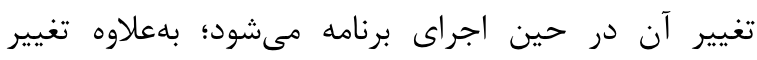

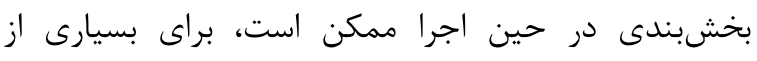

${ }^{1}$ Computation offloading 


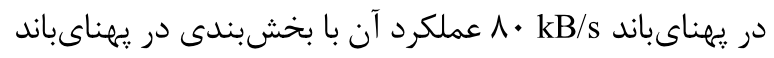

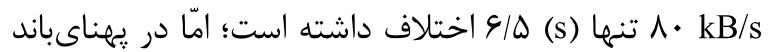

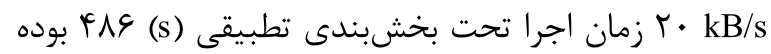

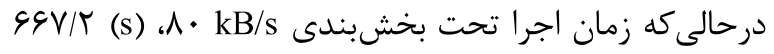

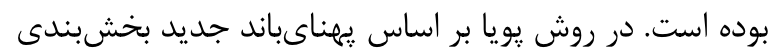

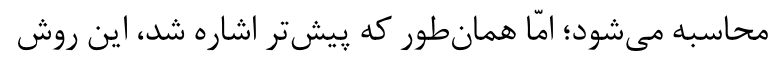
محدوديتهايى دارد.

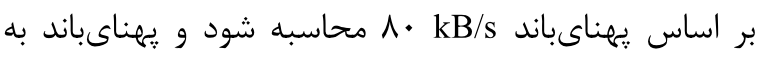

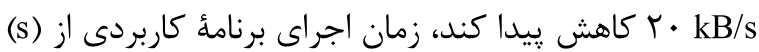

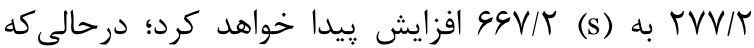

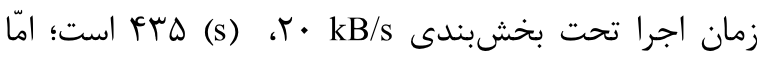
بخشبندى تطبيقى كه مانند روش ايستا يكبار محاسبه مىشود و در حين اجراى برنامه كاربردى تغيير نمى بندي،

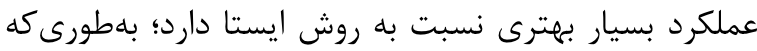

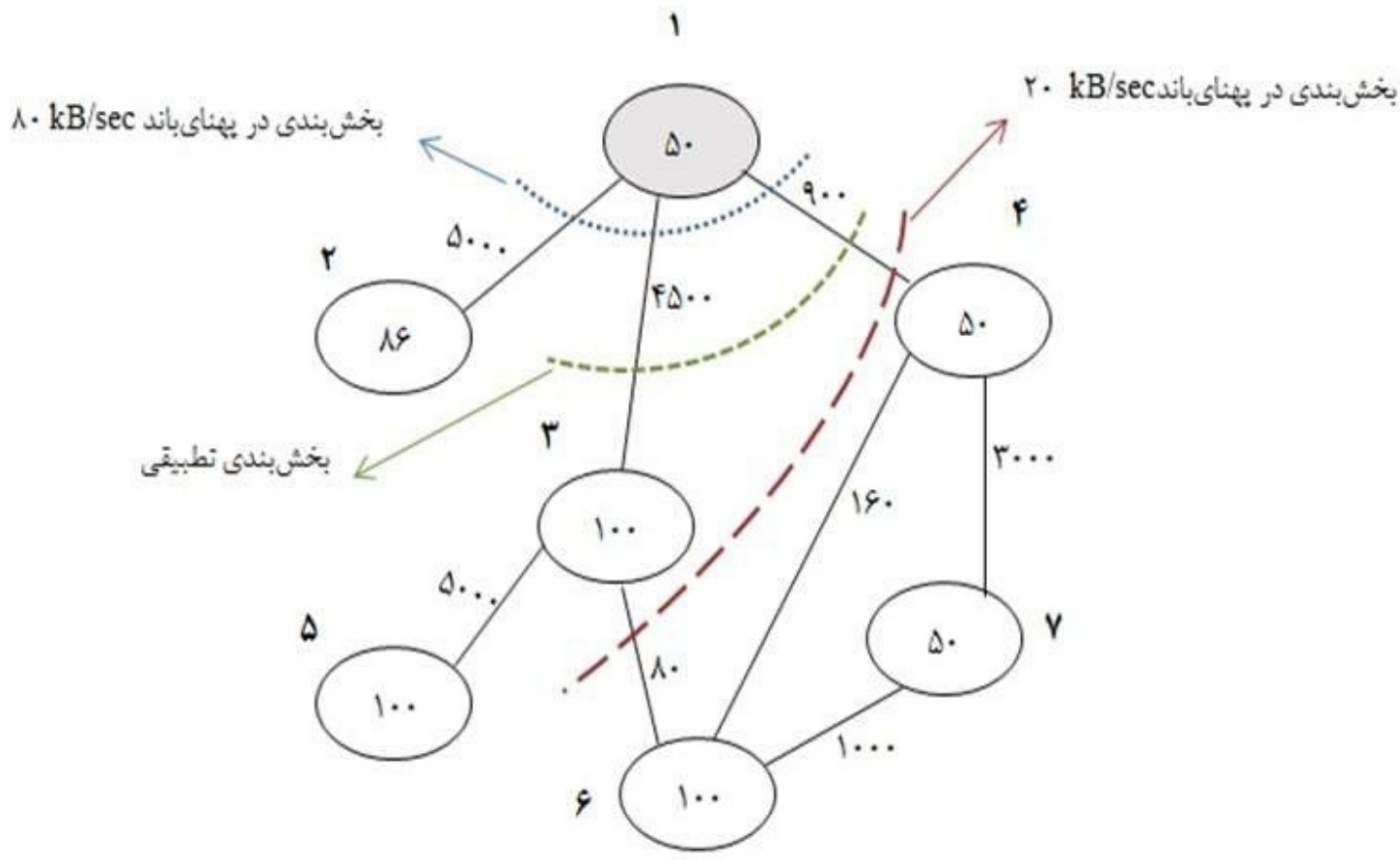

WORGs (شكل - (): نمايش برنامة كاربردى با استفاده از

(Figure-1): Demonstration of Application using WORGs

مىتواند با تغيير شرايط مسأله حتى منجر به برونسيارى

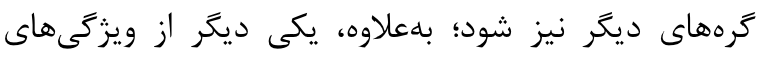

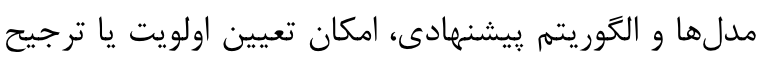

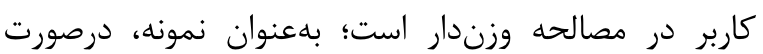
انتخاب كاربر براى مصرف يهناى باند كمتر، مصالحه با

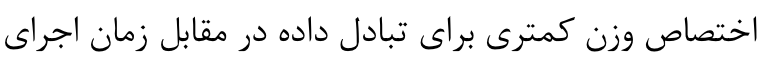
كد و ميزان مصرف انرزى صورت مى

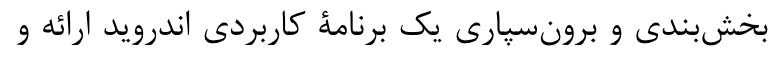

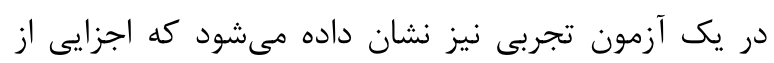
برنامة كاربردى كه محاسبات زياد و تبادل دادة كمى نياز دارند، نامزدهاى بهترى براى برونسيارى هستند.

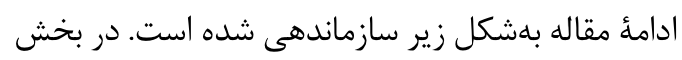
r كارهاى بيشين و در بخش r فرضيات مسأله بيان شده است. در بخش f أمدلهاى بخشبندى بيشنهادى، در بخش ه الكَوريتم بخشبندى و در بخش ع ارزيابى كارايى الكوريتم بنه
در اين مقاله سه مدل بخشبندى تطبيقى با تغييرات يهناىباند، با اهداف متفاوت شامل بهينهسازى () زمان اجرا،

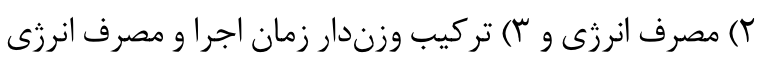
بلمنظور بخشبندى برنامههاى كاربردى موبايل ارائه مىشود.

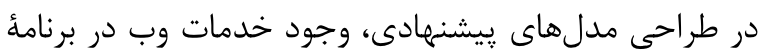
كاربردى و محدوديتهاى احتمالى تبادل داده مورئه مورد تأكيد

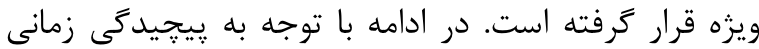
بالاى اين مدلهاى بهينهسازى يك روش بخشبندى مبتنى

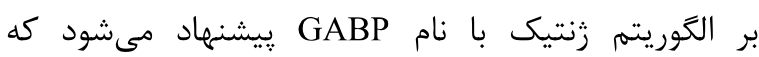
بخشبندى مناسبى را در زمان معقول انجام مىدهد. مدلها و روش ويشنهادى، قابليت استفاده در بخشبندى ايستا و يويا

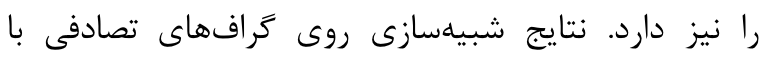

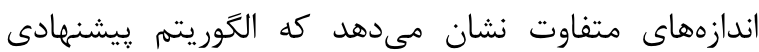
نسبت به روشهاى ديخر بهبود كارايى قابل توجهى دارد.

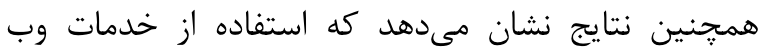




\section{r - كارهاى بيشين}

يزوهشهاى متعددى در زمينهُ برونسيارى اجرا و بخشبندى

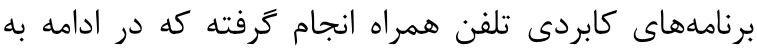

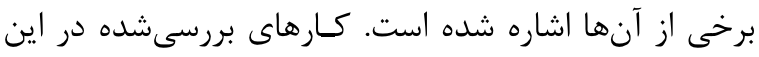
بخش در جدول (r) آورده شده است.

(جدول - (Y): مقايسُٔ برخى كارهاى انجامشده با رويكرد ايستا و يويا (Table-2): List of Related works with Static/Dynamic Approaches

\begin{tabular}{|c|c|c|c|}
\hline ييادهسازى & 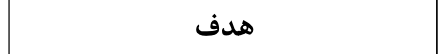 & 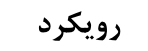 & 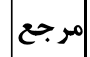 \\
\hline 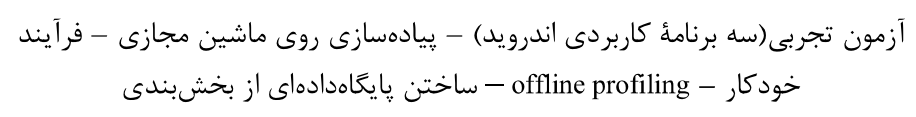 & كاهش زمان اجرا و مصرف انرزى & 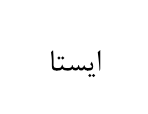 & {$[6]$} \\
\hline شبيهسازى روى كراف تصادفى & 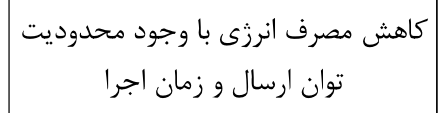 & 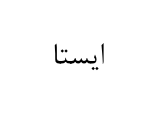 & [7] \\
\hline آزمون تجربى (سه برنامة كاربردى اندرويد) - يِيشبينى زمان اجراو يهناىباند & اجرا با وجود محدوديت زمانى- كاهش مصرف انرزى & 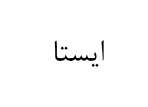 & {$[8]$} \\
\hline آزمون تجربى - بِيادهازى الكَوريتم مرتبسازى (در اندرويد) و برونسيارى آن روى & 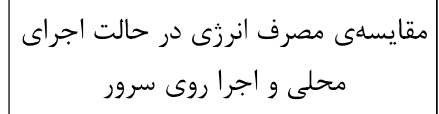 & 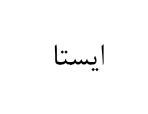 & [9] \\
\hline الرائهى الكوريتمهاى بخشبندى- شبيdسازى روى كراف تصادفى & 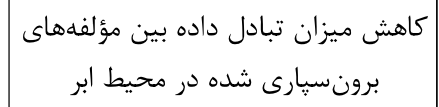 & 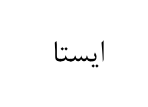 & {$[10]$} \\
\hline آزمون تجربى(سه برنامهى اندرويد) - فرآيند خودكار (با دخالت جزئى توسعهدهنده) & كاهش مصرف انرزى & 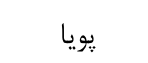 & {$[11]$} \\
\hline آزمون تجربى (دو برنامهٔ اندرويد) - فرآيند خودكار (استفاده از bytecode) & كاهش زمان اجرا و مصرف انرزى & يويا & {$[12]$} \\
\hline آزمون تجربى(دو برنامةٔ اندرويد) - نياز به بِيادهازى برنامه توسط توسعهدهنده در دو & كاهش زمان اجرا & نيمهيويا & {$[13]$} \\
\hline 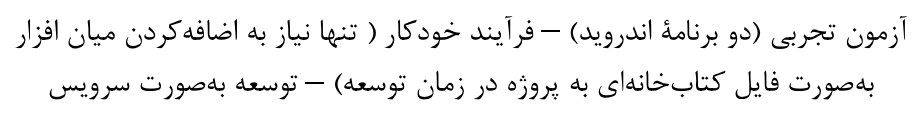 & كاهش زمان اجرا و مصرف انرزى & يويا & {$[14]$} \\
\hline فرآيند خودكار & كاهش زمان اجرا، مصرف انرزى و تأخير | & يويا & {$[15]$} \\
\hline 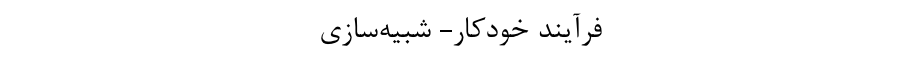 & كاهش مصرف انرزى در دستخاههاى IoT & يويا & {$[15]$} \\
\hline ارائه مدلها و الكوريتمهاى بخشبندى با در نظر گرفتن تغييرات يهناىباند- شبيهسازى رواف واقعى و تصادفى & كاهش زمان اجرا و مصرف انرزى (مدل & 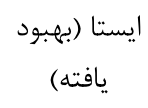 & [4] \\
\hline
\end{tabular}

لائٔ كاربرد مـاشينهاى مجازى مانند Java VM Javik

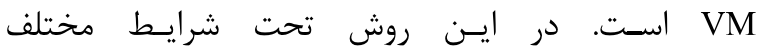
بخشبندى هاى متفاوتى محساسبه و در يايكاهداده ذخيره و
ييشنهادى با توجه به مدل ها ارائه و در بخش V لخشبندى و

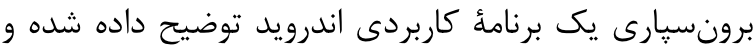
درنهايت در بخش 1 نتيجه كيرى انجام گرفته است. 
ردهها بلهورت يك خدمات روى سرور پيادهسازى مىشوند. براى برونسيارى در زمان اجرا تنها يك شرط بررسى مى رهود و آن هم در دسترسبودن منابع سرور است و اتر منابع سرور در دسترس باشند، خدمات سمت سرور فراخوانى مىشود؛ در غيراينصورت نسخة محلى خدمات (كلاس) روى تلفن هوشمند، اجرا مىشود. ميانافزار MACS [14] براى بخشبندى و برونسيارى خودكار برنامههاى كاربردى اندرويد طراحى شده است. تنها كافى است، توسعهدهندگان بخشهايى را كه نياز به يردازش زياد دارند، بهصورت خدمات [16] ييادهسازى و فايلهاى كتابخانهاى MACS را به يروزه خود اضافه كنند. در اين روش بر اساس مدلهاى هزينه و با بال توجه به زمان اجرا، ميزان حافظه و مصرف انرزى (مصرف انرزى صفحهُ نمايش نيز در نظر گرفته مىشود) بخشبندى

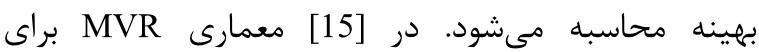
برونسيارى اجراى برنامههاى كاربردى با تعامل/محاسبات زياد در Cloud Edge و استفاده از منابع مجازى (VRs) اريائه شده است. MVR روى دستخاه موبايل داراى ينج مؤلفه و هر VRs سهلائُ جديد از جمله ابر، MEC وإنائه و ويك طرح برونسيارى انتخابى براى كاهش مصرف انرزى دستخاههاى IoT و همجنين كاهش سربارهاى سيخَنالينَ MEC داده شده است. در [4] بخشبندى تطبيقى با يهناىباند و يك الخوريتهم مبتنى بر Branch and Bound و يك الگوريتم حريصانه به نام MCGAP ارائه و براى بلهدستآوردن

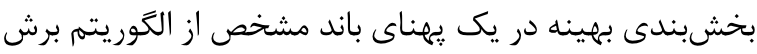

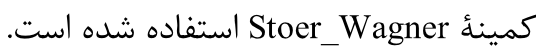

در كارهاى مرورشده در جدول (1) استفاده از خدمات

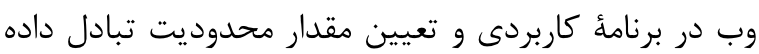
در نظر گرفته نشده است. در مدلها و الگوريتم ييشنهمادى اين

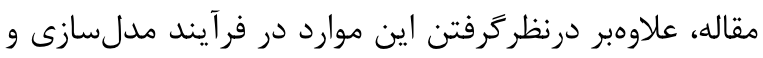

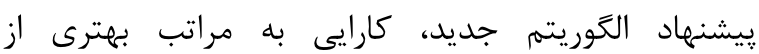
الكوريتمهاى ييشين بهدست آمده است.

\section{r - فرضيات}

در اين بخش فرضيات مسأله بيان مىشود. در مدلهاى

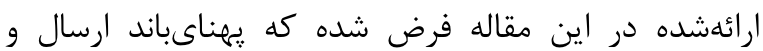
دريافت برابر است و دستخاه تلفن همراه از Wi-Fi بهعنوان واسط شبكه استفاده مى كند؛ همجنين توان ارسال و دريافت Wi-Fi براى دريافت ياسخ بخش برونسيارىشده نيز صرفنظر و
در هنخام اجرا بر اساس شرايط يكى از بخشبندىها روى

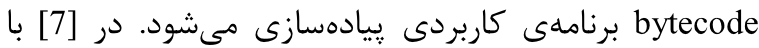
درنظرگرفتن يك محدوديت توان ارسال و يك محدوديت تأخير (با توجه به زمان اجرا و زمان انتقال داده مورد نياز)، بخشبندى و تخصيص منابع راديويى (توان ارسال و و ومان (constellation size با هم (jointly) بdنحوى انتخاب مىشود كه مصرف انرزى برنامه كاربردى روى تلفن همراه كمينه شود. در [8] يك معمارى براى برونسيارى ارائه شده است.

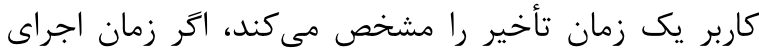
برنامةٔ كاربردى (زمان اجرا تخمين زده ميىشود) بيشتر از

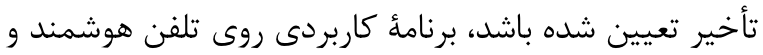
بر بخشبندى مىشود. در غير اين صورت مصرف انرزى بررسى مىشود و اگر برونسيارى موجب كاهش مصرف انرزى شود برنامئ كاربردى بخشبئدى مي شودود. در [9] يك مدل مقايسهاى براى مصرف انرزى ارائه شده است و مصرف انرزى هنگام اجراى يك كد با محاسبات

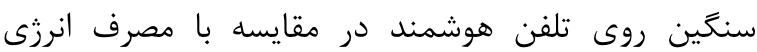
انتهابهانتها درحالتى كه كد روى سرور اجرا مىشود، مقايسه و همجنين بهبود عملكرد و مصرف انرزى در دو حالت استفاده

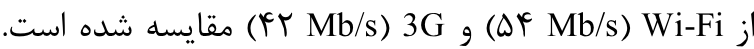
در مرجع [10]، يك روش بخشبندى براى مؤلفههاى

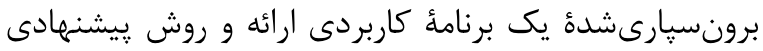

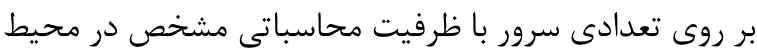
بر اجرا شده است. هدف اصلى، كاهش نرخ تبادل داده ميان مؤلفههاى برونسيارىشده و در نتيجه، كمينهكردن تأخير است. براى بلدستآوردن بخشبندى الكوريتمهاى مكاشفهاى ارائه شده است. جهارجوب MAUI [11] برونسيارى در سطح تابع را يشتيبانى مى كند، توسعهدهنده بايد توابع يا ردههايى

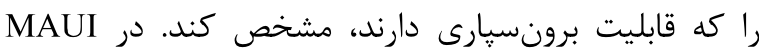

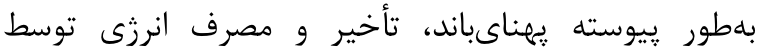
بخش Profiler اندازهزيرى مىشوند و بخشبندى بهينه با توجه به مصرف انرزى توسط بخش Solver با استفاده از برنامهريزى خطى محاسبه مىشود. در [12] برونسيارى در سطح رده و با هدف بهبود عملكرد و ذخيرة انرزى انجام مى گيرد. براى كاهشدادن سربار تصميم گيرى، ردههاى برنامئ

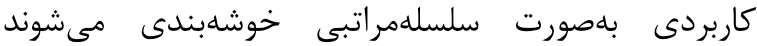
بهطورى كه ردههايى كه با يكديگر ارتباط زيادى دارند (از نظر

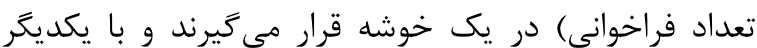
برونسيارى مىشوند. در [13] توسعهدهنده تعيين مى كند كه جه ردهايى از برنامه كاربردى اندرويد برونسيارى شوند و اين 
در ادامه سه مدل براى بخشبندى برنامه كاربردىهاى

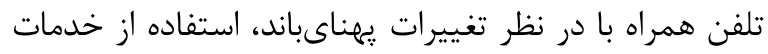
وب در برنامه كاربردى و محدوديت مبادله داده ارائه مىشود.

\section{|-1-1- مد - مدل بهينهسازى زمان اجرا}

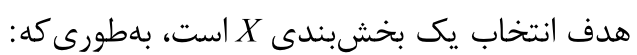

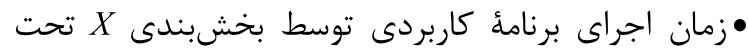
يجناىباند b، يعنى (

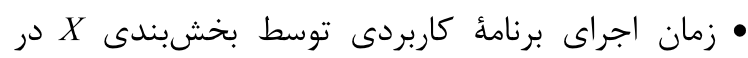
يهناىباند إb، يعنى

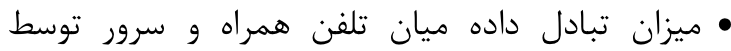
بخشبندى Xata(X) ميشنى

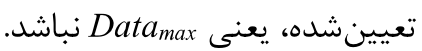

•به اين ترتيب فضاى راهحل مدل Xd براى محاسبئ بخشبندى تطبيقى با يهناىباند با درنظر مرفتن محدوديت

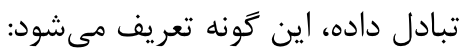
$X_{d}=\left\{X \mid T_{w s}\left(X, b_{l}\right) \leq T_{w s}\left(X_{b_{l}}^{o p t}, b_{l}\right) \times(I+\alpha)\right.$ and $\left.\operatorname{Data}(X) \leq \operatorname{Data}_{\max }\right\}(Y)$ • كه در آن ${ }^{\top} T_{w s}\left(X_{b_{l}}^{o p t}, b_{l}\right)$ توسط بخشبندى بهينه $X_{b_{l}}^{\text {opt }}$ ثابت تجربى a $a>0$ (a) ) زمان اجراى (

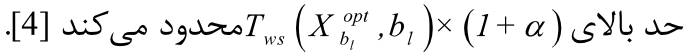
اگر مقدار a خيلى كو جكى انتخاب شود، ممكن است بخشبندى كه شرط نخست موجود در X

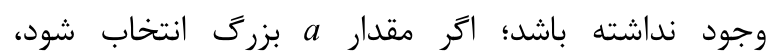
بهوطوى كــهـ اين صورت بخشبندى بهينه تحت يهناى باند b، يعنى $X_{b l}^{o p t}$ بهعنوان راه حل انتخاب مىشود.

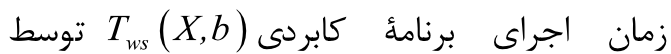
بخشبندى X تحت يهناىباند b طبق رابطة زير تعريف

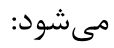

$$
T_{W S}(X, b)=\sum_{1 \leq i \leq n}\left(x_{i} \times t_{n i}+\left(1-x_{i}\right) \times t_{n i}\right)+\sum_{1 \leq i<j \leq n}\left|x_{i}-x_{j}\right| \times t_{i j}+\sum_{1 \leq i \leq n_{s}} t_{w s i}\left({ }^{\top}\right)
$$

كه در آن زمان اجراى گره i روى سرور (thsi) برابر است با

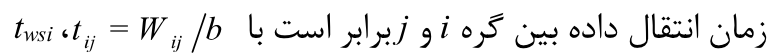
زمان نهايى اجراى خدمات وب شماره i ران نشان مىدهد و بان إنا توجه به نوع خدمات وب محاسبه مىشود. براى خدمات وب نوع نخست
همجنين فرض شده است كه گراف برنامهُ كاربردى موجود است. در اين مقاله براى بازنمايش برنامهٔ كاربردى از گراف

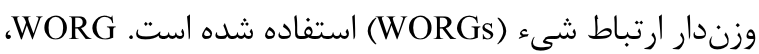
يك گراف غير جهتدار است كه در آن رأسهاى ردهـهاى ردهاى برنامة كاربردى و يالها ارتباط بين ردهها را نشان مى يدهد و وزن رأسها زمان اجراى ردهها روى دستخاه تلفن همراه و وزن ئن

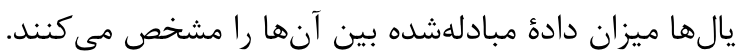

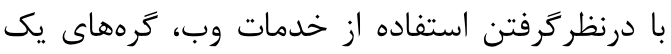

برنامئ كاربردى به سه دسته تقسيم مىشوند: I. گرههايى كه بايد باصصورت محلى و روى تلفن همراه اجرا شوند. r. ₹رههايى كه بdصورت خدمات وب تعريف مىشوند (روى تلفن همراه اجرا نمىشوند) و شامل دو نوع هستند: •خدمات وب نوع نخست، بخشهايى از برنامهٔ كاربردى كه

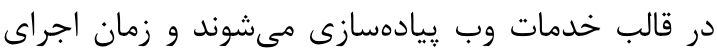
آنها در سامانه محلى (موبايل) معلوم است. •خدمات وب نوع دوم، وبسرويسهاى سازمانهاى ديكر كه مورد استفاده قرار مى گيرند و زمان اجراى آنها به صوريه صورت يك مقدار متوسط تعيين مىشود. س. گ گههايى كه قابليت برونسيارى دارند.

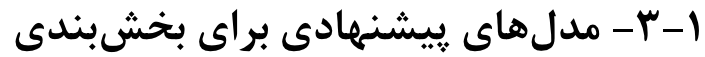
در اين بخش مدلهاى بخشبندى را با توجه به زمان اجرا و

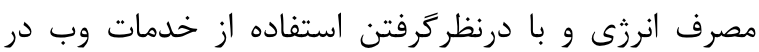
برنامةٔ كاربردى و محدوديت تبادل داده ارائه ميىدهيم.

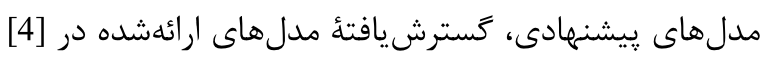
هستند. علائم به كاربردهشده در مدلها در جدول (ז) آورده

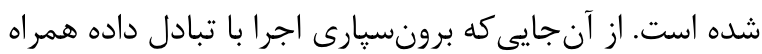
است با تعيين يك محدوديت مبادلل داده ميزان تبادل داده بين تلفن همراه و سرور را كنترل كرد. در

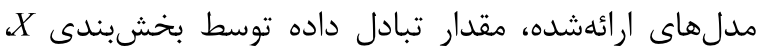

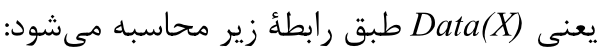

$$
\operatorname{Data}(X)=\sum_{1 \leq i<j \leq n}\left|x_{i}-x_{j}\right| \times W_{i j}
$$

كه در آن نتيجة بخشبندى گره $i$ است (1=1 روى تلفن همراه اجرا مىشود؛ و $0=0$ مىشود). رابطه ( (1) ميزان تبادل داده بين گرههايى را نشان مىدهد كه با يكديگر در ارتباط هستند ( بخشبندى X روى يك سامانه اجرا نمىشوند ( 
كرهها كاربردى موجب مى شود كه در حالت اجراى محلى نيز هزينه ارتباطى وجود داشته باشد؛ به اين ترتيب تغييرات بِهناى دانداند

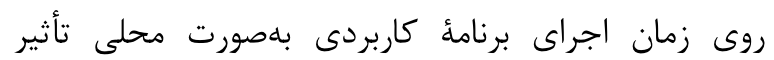
مى عذارد. رابطؤ (r) يك مسألهُ بهينهسازى است كه براى بلهدست آرودن بخشبندى (تطبيقى) بهينه در بدترين حالت،

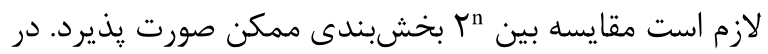
اين مقاله در بخش ه روشى مبتنى بر الكوريته زنتيك براى آن ارائه مى كنيم.
روى موبايل است، براى خدمات وب نوع دوم

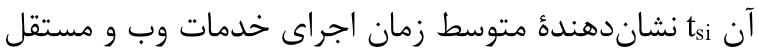
از

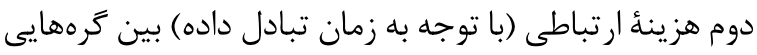

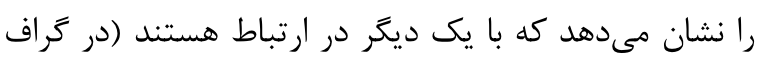
برنامئ كاربردى بين آنها يال وجود دارد) و روى يك يك سامانه

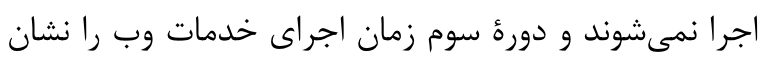
مى دهد كه براى كرهماى خدمات وب، محاسبة زمان اجراى برنامئ كاربردى بلهصورت محلى

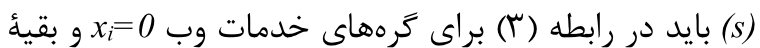

(جدول - ץ): علائم به كار رفته در مدل بخشبندى بيشنهادى

(Table-3): Notations for the proposed partitioning method

\begin{tabular}{|c|c|}
\hline 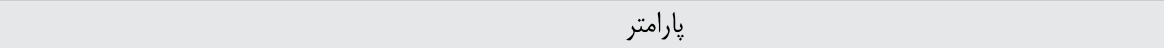 & برجسي \\
\hline مقدار داده مبادلهشده بين تلفن همراه و سرور تحت بخشبندى X & $\operatorname{Data}(X)(K B)$ \\
\hline بيشينة دادة مبادلهشدة مجاز بين تلفن همراه و سرور & $\operatorname{Data}_{\max }(K B)$ \\
\hline زمان اجراى برنامه كاربردى توسط بخشبندى X تحت يهناى & $T_{w s}(X, b)(s)$ \\
\hline بخشبندى برنامه كاربردى كه به صورت X= x $x_{1}, x_{2}, \ldots$ تعريف مى شود & $x$ \\
\hline نتيجة بخشبندى گره i، i...n & $x_{i}$ \\
\hline تعداد كل گرههاى برنامٔ كاربردى & $N$ \\
\hline 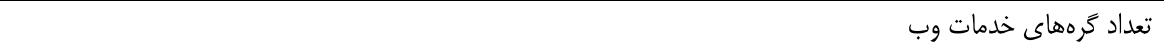 & $n_{s}$ \\
\hline يهناى باند فعلى & $b(k B / s)$ \\
\hline يهناىباند كمينه & $b_{l}(k B / s)$ \\
\hline زمان اجراى محلى كرءٔ i روى تلفن همراه & $t_{n l i}(s)$ \\
\hline زمان اجراى گرء أ روى سرور & $t_{n s i}(s)$ \\
\hline زمان اجراى خدمات وب i را نشان مىدهد & $t_{s i}(s)$ \\
\hline زمان نهايى اجراى خدمات وب ارا نشان مى دهد & $t_{w s i}(s)$ \\
\hline نسبت زمان اجراى يك گره روى سرور به زمان اجراى آن روى تلفن همراه & K \\
\hline دادة مبادلهشهه بين گَرههاى i و ز & $W_{i j}(K B)$ \\
\hline زمان انتقال داده بين گَرهاى أو ز & $t_{i j}(s)$ \\
\hline مصرف انرزى برنامه كاربردى توسط بخشبندى X تحت يهناىباند b & $E_{w s}(X, b)(J)$ \\
\hline انرزى مصرفى كرئ أ زمانى كه بلطور محلى روى موبايل اجرا شود & $E_{i}(J)$ \\
\hline انرزى مصرفى براى انتقال داده بين گرههاى أ و ز & $E_{i j}(J)$ \\
\hline توان CPU موبايل CPU & $P_{c p u}(W)$ \\
\hline توان ارسال و دريافت واسط شبكه (Wi-Fi) & $P_{w}(m W)$ \\
\hline زمان اجرا در حالتى كه كل برنامؤ كاربردى بهصورت محلى اجرا مىشود. & $T_{\text {LocalWs }}(\mathrm{s})$ \\
\hline انرزى مصرفى در حالتى كه كل برنامٔ كاربردى بلهورت محلى اجرا مىشود. & $E_{\text {LocalWs }}(J)$ \\
\hline مقدار عددى وزندار (زمان اجرا و مصرف انرزى) توسط بخشبندى X و تحت يهناىباند b & $W T E_{w s}(X, b)$ \\
\hline وزن زمان اجرا در مدل بخشبندى وزندار & $w_{t}$ \\
\hline وزن انرزى مصرفى در مدل بخشبندى وزندار به طورى كه: 1 & $w_{e}$ \\
\hline
\end{tabular}

• مصرف انرزى برنامهُ كاربردى توسط بخشبندى X تحت

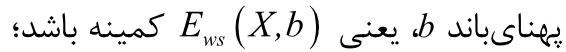

r-1-r- مدل بهينهسازى مصرف انرزى هدف انتخاب يك بخشبندى X است بلمطورى كه: 
مشابه مدل ارائهشده براى مصرف انرزى (بدون درنظركرفتن خدمات وب) در [4] است.

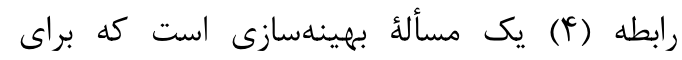

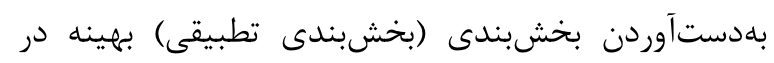

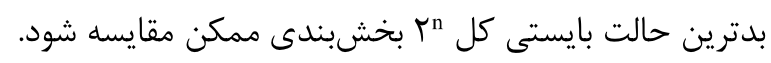

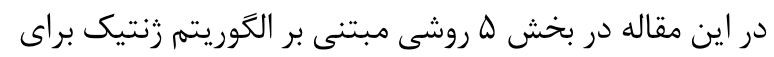

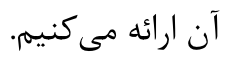

ץ-1-ץ- مدل وزندار بهينهسازى زمان اجرا و مصرف انرزى

هدف انتخاب يك بخشبندى X است، بهطورى كه:

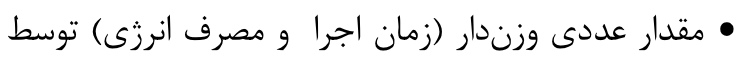

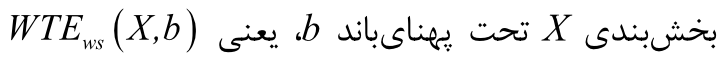

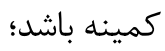

•مقدار عددى وزندار (زمان اجرا و مصرف انرزى) توسط باشئ بخشبندى X $X$ در يهناى باند إط، يعنى (X,b) يك حدى بيشتر نباشد؛

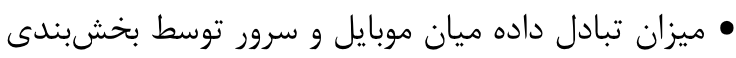

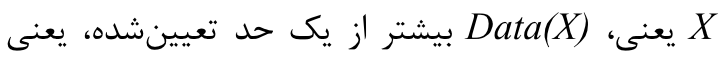

\section{نباشد. Data Dax $_{\text {max }}$}

فضاى راهحل مدل Xd X براى محاسبة بخشبندي

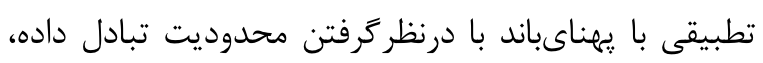

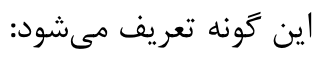

$X_{d}=\left\{X \mid W I E_{w s}\left(X, b_{l}\right) \leq W I E_{k s}\left(X_{b}^{a t}, b_{l}\right) \times(1+\alpha)\right.$ and Dtad $\left.X\right) \leq D$ tat $\left.a_{n x}\right\}$

كه در آن ${ }^{\top}$ مقدار مدل وزندار توسط بخشبندى بهينة

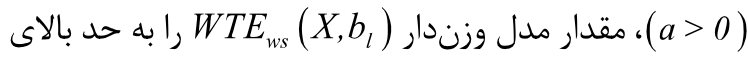
مقدو $W T E_{w s}\left(X_{b_{l}}^{o p t}, b_{l}\right) \times(1+\alpha)$

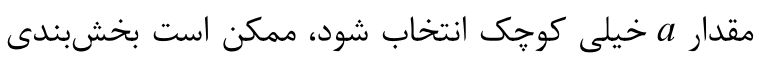
كه شرط نخست موجود در

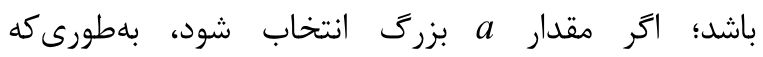
مر اين $W T E_{w s}\left(X_{b}^{o p t}, b_{l}\right) / W T E_{w s}\left(X_{b_{l}}^{o p t}, b_{l}\right) \leq(1+\alpha)$ صورت بخشبندى بهينه تحت يهناى باند b، يعنى بلهنوان راهحل انتخاب مىشود. مدل وزندار بهينهسازى زمان اجرا و مصرف انرزى

$$
\text { WTE } E_{w s}(X, b)
$$

$W T E_{w s}(X, b)=w_{t} \times T_{w s}(X, b) / T_{\text {Lodus }}+w_{e} \times E_{\text {ws }}(X, b) / E_{\text {LoodlWS }}(\mathrm{V})$
•مصرف انرزى برنامة كاربردى توسط بخشبندى X در

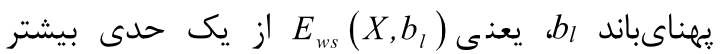
نباشد؛

• ميزان تبادل داده ميان تلفن همراه و سرور توسط

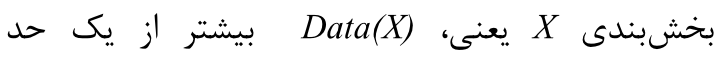
تعيينشده، يعنى Data

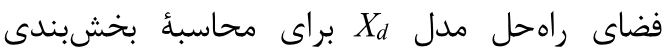

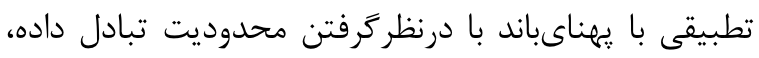
اين گونه تعريف مىشود: $X_{d}=\left\{X \mid E_{w s}\left(X, b_{l}\right) \leq E_{w s}\left(X_{b_{l}}^{o p t}, b_{l}\right) \times(1+\alpha)\right.$ and $\left.\operatorname{Data}(X) \leq \operatorname{Data}_{\max }\right\}$

كه در آن ${ }^{\top} E_{w s}\left(X_{b_{l}}^{o p t}, b_{l}\right)$ كاربردى توسط بخشبندى بهينه

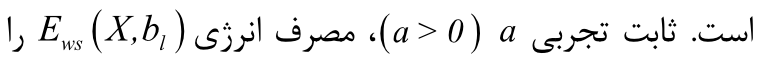

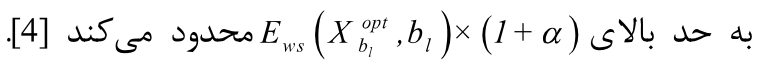

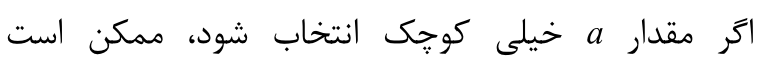

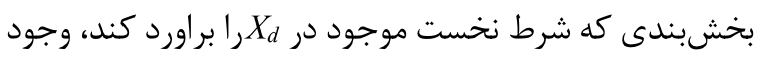

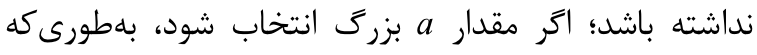
صور $E_{w s}\left(X_{b}^{o p t}, b_{l}\right) / E_{w s}\left(X_{b_{l}}^{o p t}, b_{l}\right) \leq(1+a)$ بخشبندى بهينه تحت يهناى باند b، يعنى

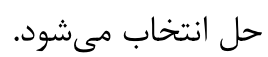
مصرف انرزى برنامة كابرد ى (X) بخشبندى X

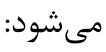
$E_{w s}(X, b)=\sum_{1 \leq i \leq n}\left(x_{i} \times E_{i}\right)+\sum_{1 \leq i<j \leq n}\left|x_{i}-x_{j}\right| \times E_{i j}$ كه در آن

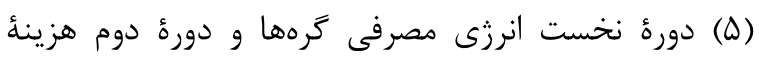

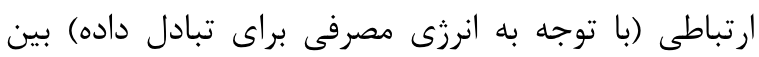
كرههايى را نشان مىدهد كه با يكديكر در ارتباط هستند و

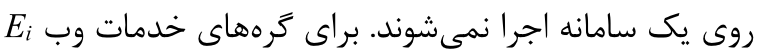
(t) كاربردى بلهورت محلى (JocalWS كرههاى خدمات وب

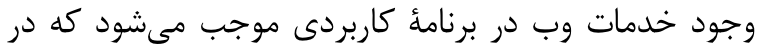

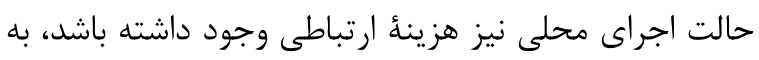

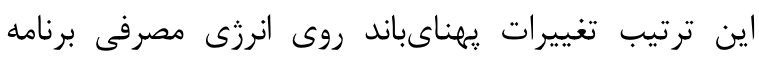

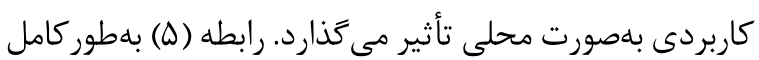


I. مجموعة كرههايى كه در بخشبندى بهينه تحت يهناىباند كمينه (b) در وضعيت برونهيارى (x) (x) يعنى $S_{b_{l}}$ در بخشبندى بهينه تحت يهناىباندهاى بالاتر

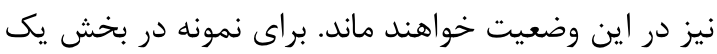

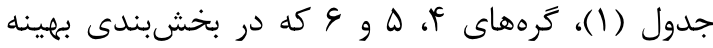

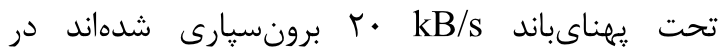

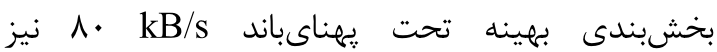
برونسيارى شدهاند.

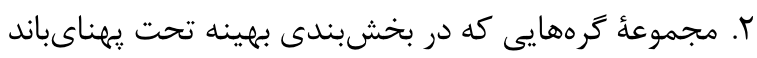

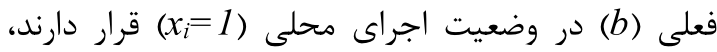
يعنى $C_{b}{ }$ يايينتر نيز در اين وضعيت خواهند ماند؛ به اين ترتيب

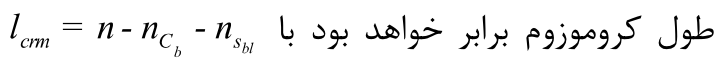

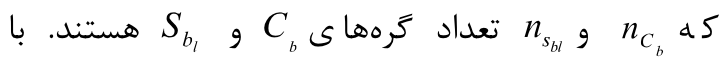

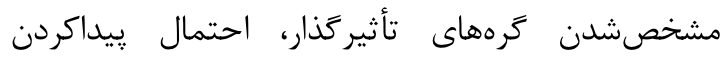
بخشبندى تطبيقى بهينه افزايش مىيابد. در شكل (r)

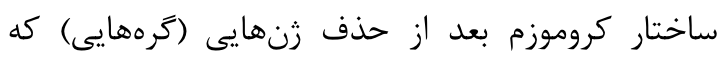

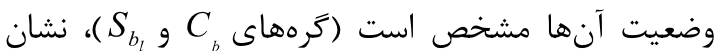

داده شده است.

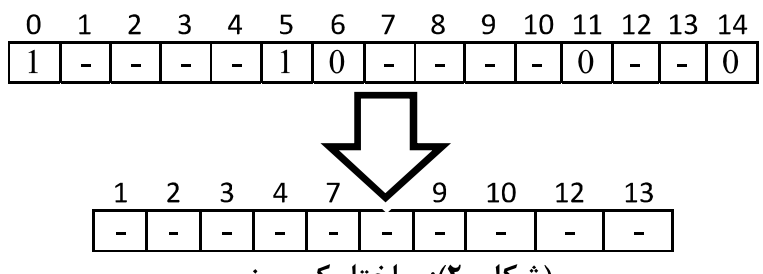

(شكل-r): ساختار كروموزوم

(Figure-2): Chromosome Structure

شبهكد روش ڤيشنهادى در الخوريتم (1) نشان داده

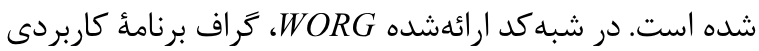

در خطوط اوץ براى تعيين حد بالا، مقدار بهينـة مدل

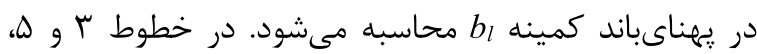
b بر اساس بخشبندى $C_{b}{ }_{b} S_{b_{l}}$

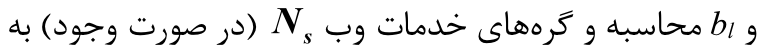

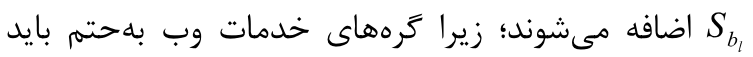
برونسيارى شوند. در خط و و \ بهصورت تصادفى و بهاندازه

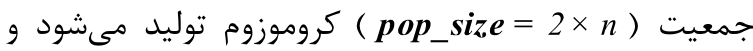
براى جلوكيرى از توليدشدن كروموزومهاى تكرارى، تعداد

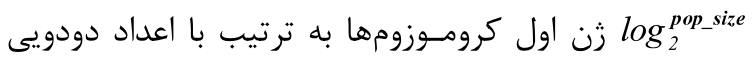

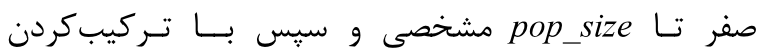

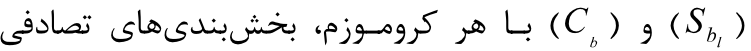
توليد مىشود (كنترل مىشود كه تا حد امكان تعداد
كه در آن EocalWS $T_{\text {LocalWS }}$ بهترتيب برابر هستند با زمان اجراو مصرف انرزى زمانى كه برنامة كاربردى به صورت

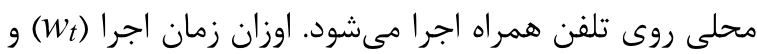

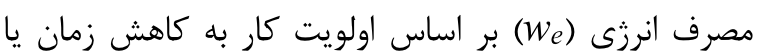

$$
\text { مصرف انرزى تعيين مىشوند. }
$$

رابطه (ع) يك مسأله بهينهسازى است كهئ كه براى بهدستآرودن بخشبندى (بخشبندى تطبيقى) بهينه در بدترين حالت بايستى كل بn بخ بخشبندى ممكن مقايسه شود.

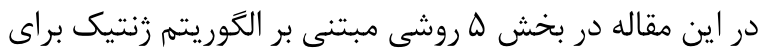

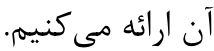

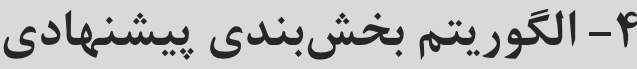

همانطور كه پيشتر اشاره شد، در يك برنامd كاربردى با مؤلفه، ييداكردن بخشبندى بهينه با در نظر گفتن محدوديت

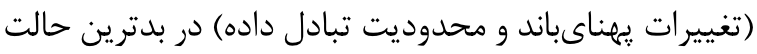

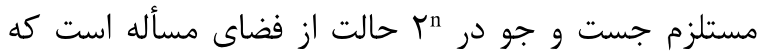
براى برنامههايى با تعداد مؤلفئ بزرگتر از بيست، ييداكردن

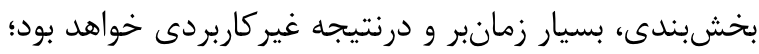

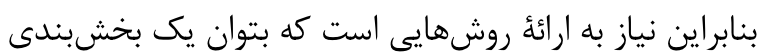

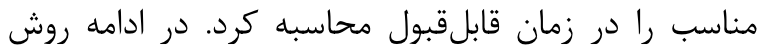
ابتكارى مبتنى بر الخوريتم زنتيك (GBAP) براى تعيين

بخشبندى با توجه به مدلهاى ييشنهادى ارائه شده است.

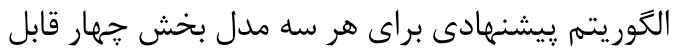

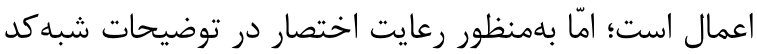
اين بخش، از مدل وزندار استفاده مىشود كه حالت كلى بوده و دو مدل قبلى را نيز شامل مىشود. در ادامه منظور از

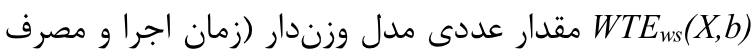

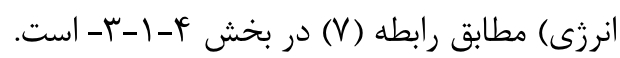

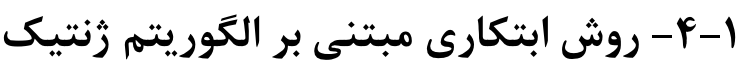

در اين بخش الكوريتم بخشبندى يِيشنهادى توضيح داده

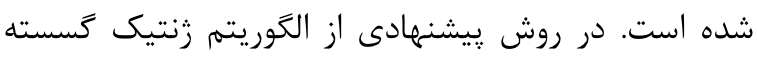
استفاده شده است. ساختار كروموزوم در شكل (r) نشان داده شده است. هر زن نماينده يك گره است كه داراى مقدار يك يا صفر است و طول هر كروموزوم برابر با تعداد گرههايى است كه وضعيت آنها مشخص نيست، به اين ترتيب گرههايى كه در وضعيت برونسيارى قرار دارند و گرههايى كه بايد روى

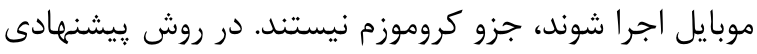

از دو استدلال زير استفاده شده است [4]: 
مىشود؛ سيس تعداد بهطور تصادفى از بين كل جمعيت انتخاب و از هركدام يك

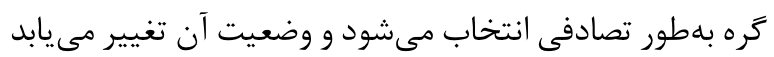

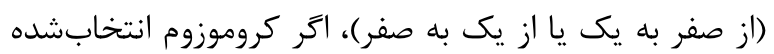
جز و كروموزوم برتر باشد، تغيير

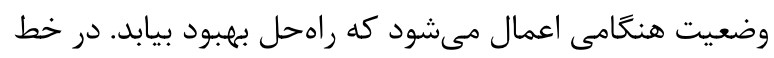
دوازده مقدار مدل تحت بخشبندى هـاى جديد توليد شده كه

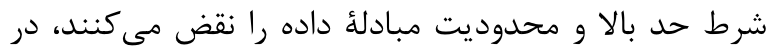

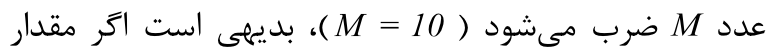
Datamax كرفته نمىشود و در انتخاب بخشبندى تطبيقى تأثيرى نمى گذارد. در ادامه بخشبندى دها بر اساس مقدار مدل مرتب

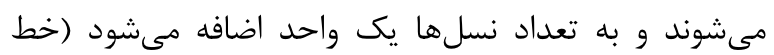

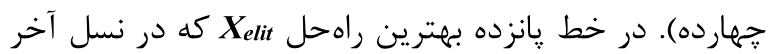

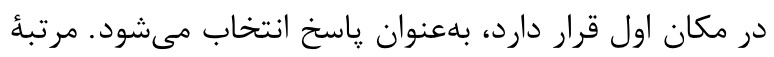
زمانى روش ييشنهادى برابر است با:

$F(n)=O\left(n_{\text {pop_size }} \times \max \_g e n \times(F s(n)+F c(n))\right)$

كه در آن مرتبهُ اجرايى مرتبسازى و عملكر crossover هستند (crom طول كروموزوم است).
و بخشبندى معتبر توليد شود) pop_size × mu_rate

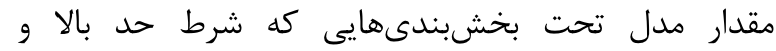
محدوديت مبادلة داده را نقض ميى كنند در عدد M $M$ ضرب مىشود (

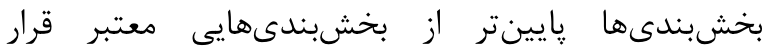

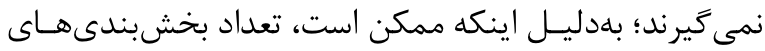

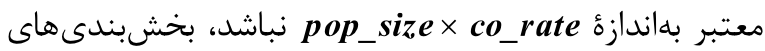

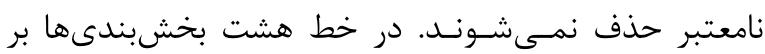
اساس مقدار مدل مرتب مىشوند (با استفاده از مرتبسازى

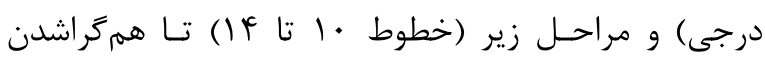
الخوريتم ） رسيدن به بيشينة تعداد نسل (max_gen) تكرار مىشود. در خطهاى • ا و 1ا با توجه به نرخ crossover (co_rate) و

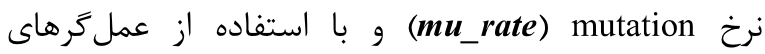
crossover و كروموزومهاى جديد (نسل جديد) توليد مىشود. انتخاب كروموزومها براى عمل crossover توسط جرخ رولت و براساس رتبه انجام مى گيرد و براى توليد two كروموزوم جديد از روش pop_size × (1 - co_rate $)$ point crossover كروموزوم بهطور تصادفى انتخاب و در هر دو كروموزوم نيز دو نقطه بهطور تصادفى انتخاب و رنهاى بين آنها جابه

Input: $W O R G, b, b_{1}, a, p o p_{\_} s i z e, c o \_r a t e, m u \_r a t e, \max _{-} g e n, N_{s}$, Data $\max$

Output: The best partitioning solution $X_{\text {elit }}$ and model value $\left(W T E_{w s}\left(X_{\text {elit }} b\right)\right)$;

\section{Begin:}

1: Compute the WTE $E_{w s}\left(X_{\text {elit }} b_{l}\right) ; / / X_{b_{l}}^{o p t}$ is the optimal partitioning in minimum bandwidth (i.e. $b_{l}$ )

2: minValue $=W T E_{w s}\left(X_{b_{l}}^{o p t} b_{l}\right) ; / /$ upper bound, equation (7) in section 4-1-3

3: Add nodes in $X_{b_{l}}^{o p t}$ where $x_{i}=0$ and nodes in $N_{s}$ to $S_{b_{l}}$;

4: Compute $W T E_{w s}\left(X_{b_{l}}^{o p t} b_{l}\right)$

5: Add nodes in $X_{b_{l}}^{\text {opt }}$ where $x_{i}=l$ and nodes in $C_{b}$; // $X_{b_{l}}^{\text {opt }}$ is the optimal partitioning in current bandwidth (i.e. b)

6: Initialize pop_size;

7: Exclude non_satisfying solutions; //upper bound and Data $a_{\max }$ are used here

8: Sort the population based on model value;

9: While (current_generation $\leq \max _{\text {gen }}$ and no_convergence ()$)$

10: Keep first pop_size $\times$ co_rate solutions and generate pop_size $\times\left(1-c o \_r a t e\right)$ solution using crossover;

11: Mutate pop_size $\times$ mu_rate solutions;

12: Exclude non_satisfying solutions; //upper bound and Data $a_{\max }$ are used here

13: Sort the population based on model value;

14: $($ current_generation $=$ current_generation +1$)$;

End while

15: Return $X_{\text {elit }}, W T E_{w s}\left(X_{\text {elit }} b\right)$; //X $X_{\text {elit }}$ is the best solution (the chromosome located in the first place of the last generation 
r. MCGA: در اين روش، بخشبندى تطبيقى با ِيهناى

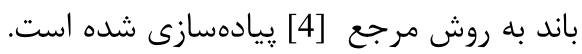

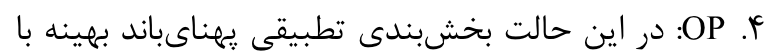

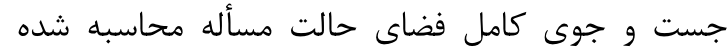

ه. Local execution اجراى محلى برنامة كاربردى روى

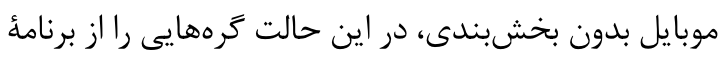

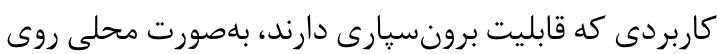

$$
\text { تلفن همراه اجرا مىشوند. }
$$

در ارزيابى انجامشده، بهترين بخشبندى درئد در دهبار اجرا

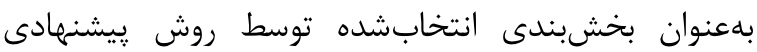

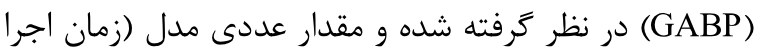
يا مصرف انرزى) توسط بخشبندى انتخابشده، با ميانكَين مقدار عددى مدل (زمان اجرا يا مصرف انرزى) توسط برديط بخشبندى هاى محاسبهشده در دمبار اجرا مقايسه شده است. در شرايط واقعى كه بخشبندى در آغاز اجراى برنامه محاسبه داسيه

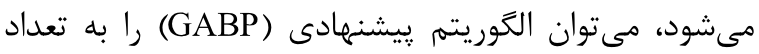

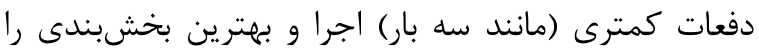

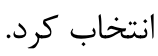

\section{1-ه- ارزيابى الكوريتهم پيششنهادى در مقايسه با راه حل بهينه}

در اين بخش ابتدا عملكرد روش بيشنهادى از نقطهنظر زمان

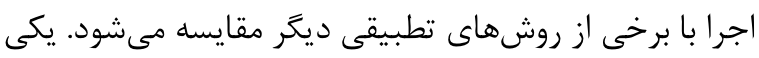

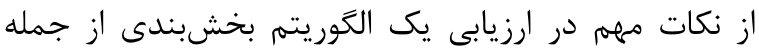

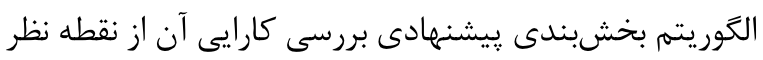

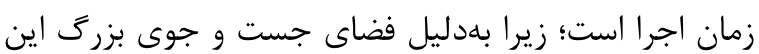

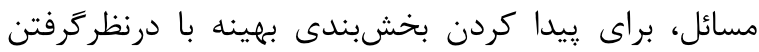

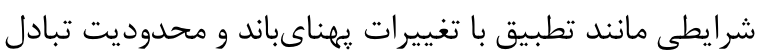

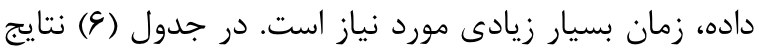

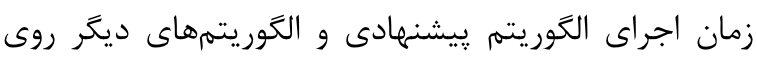

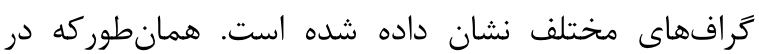
جدول مشاهده مىشود هر دو الكوريتهم تطبيقى GABP و MCGAP زمان اجراى بسيار كمترى نسبت به حالت دالت بهينه دارند، البته زمان اجراى GABP اندكى بيشتر از إز

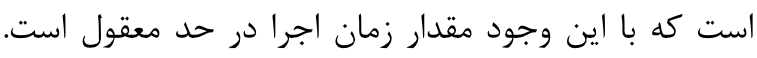
البته در قبال زمان اجراى بيشتر كارايى الكوريتم ييشنهادى إداد

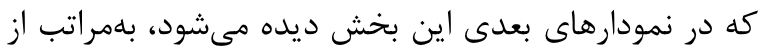

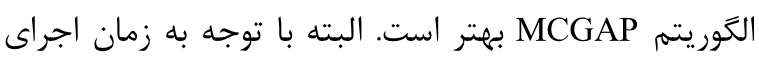

$$
\text { ه- ارزيابى كار آيى }
$$

در اين بخش كارايى مدلها و الكوريته بخشبندى يِيشنهادى (GABP)

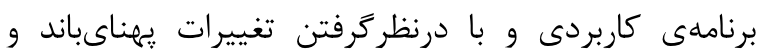
محدوديت تبادل داده ارزيابى شده است. در ارزيابى انجامشده شش تراف (WORGs) بهصورت

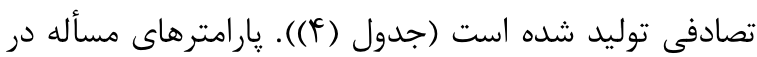
جدول (ل) نشـان داده شده است. اجراى كوتاه الكوريتهها

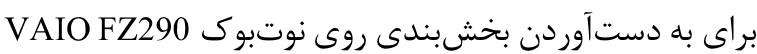

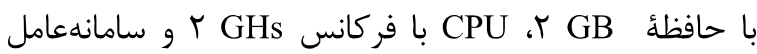
ويندوز هفت Tr بيتى و اجراهاى طولانى روى سرور

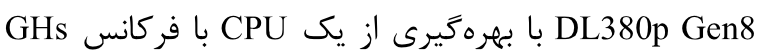

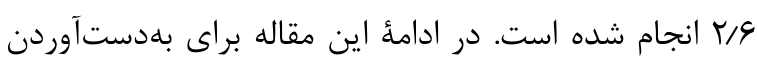
بخشبندى بهينه در يك يهناىباند مشخص از الكوريتم برش كمينه Stoer-Wagner [4] استفاده شده است. روش بيشنهادى (GABP) با حالتها و روشهاده شده است زير

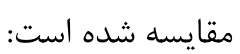

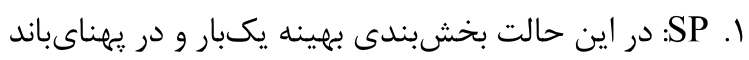
kB/sec • • ا محاسبه شده است (روش ايستا).

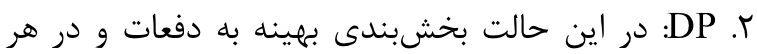
kB/sec

(جدول -WORGs: (F)

\begin{tabular}{|c|c|c|c|}
\hline تعداد يال & تعداد رأس & تعداد يال & تعداد رأس \\
\hline rks & $\Delta$. & sT & $r$. \\
\hline raf & c. & 94 & r. \\
\hline$\Delta \cdot r$ & v. & let & f. \\
\hline
\end{tabular}

(Table-4): Generated Random WORGs

(جدول -ه): مقادير بارامترهاى مسأله

\begin{tabular}{|c|c|c|}
\hline مقدار & & \\
\hline $100(\mathrm{kB} / \mathrm{sec})$ & $b$ & |كاربردىى) باند فعلى (لحظهى اجراى برنامةً \\
\hline $10(\mathrm{kB} / \mathrm{sec})$ & $b_{l}$ & إبهناى باند كمينه \\
\hline 5 & $k$ & |زمان اجراى آن روى سرور اجن بود روى موبايل به \\
\hline 0.9 (watt) & $P_{c p u}$ & توان cpu موبايل \\
\hline 1.3 (watt) & $P_{w}$ & توان ارسال و دريافت واسط شبكه (wi-fi) \\
\hline 1.2 & $a$ & 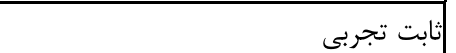 \\
\hline
\end{tabular}

(Table-5): Problem Parameters 
با حالت بهينه در جدول (VABP)، نشاندهندة دقت بالاى الكوريتم GABP

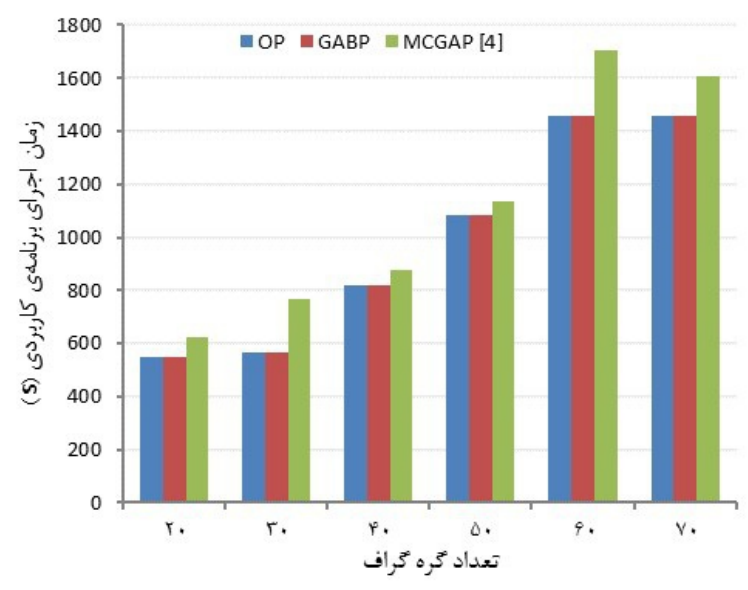

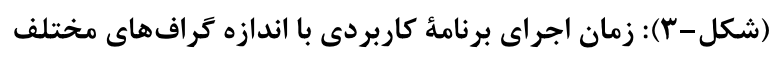

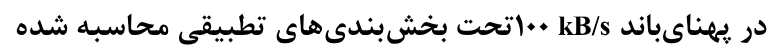
(Figure-3): Application Runtime for Various Graphs using Adaptive Partitioning

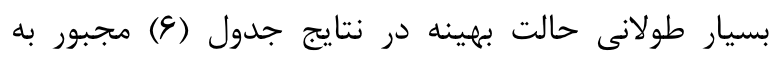
استفاده از كرافهاى با بيشينه اندازئ هفتاد كره بودهائم.

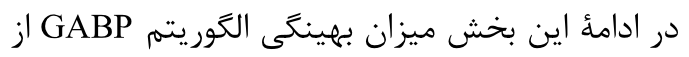

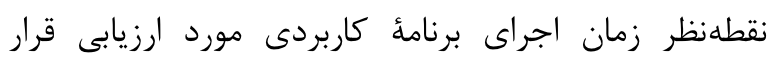

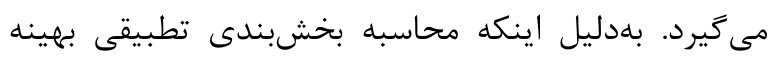

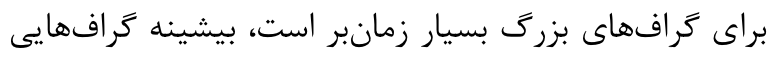

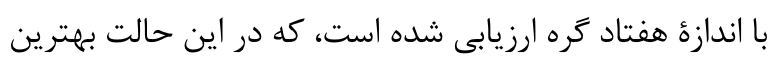

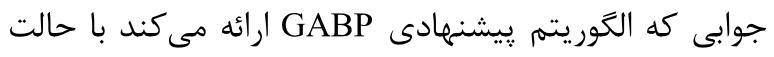

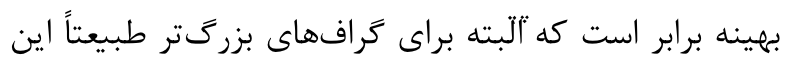

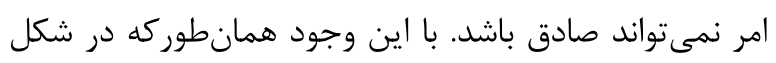

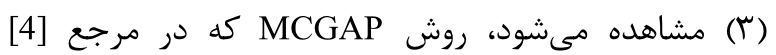

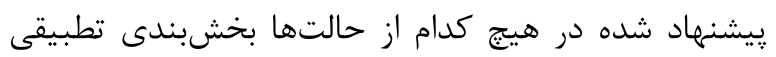

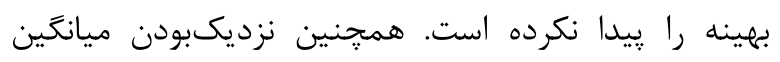
پاسخهاى بهدستآمده، توسط روش يِيشنهادى در دمبار اجرا

(جدول - (): مقايسهى زمان اجراى الكوريتمها رويكر افهاى مختلف

(Table-6): Application Runtimes on Various Graphs

\begin{tabular}{|c|c|c|c|c|c|c|}
\hline V. & 9. & $\Delta$. & f. & $r$. & $r$. & \\
\hline IFATVE & rrqpr. & $q V / A) \cdot \Delta$ & $r \cdot|\Delta \Delta| \mid$ & $r / F V V V$ & .1 .91$. & OP \\
\hline T/MTS & $1 / F \cdot r \Lambda$ & $\cdot / \vee \vee \cdot \wedge$ & . & $\cdot / 11 \%$. & $\cdot / \cdot F V \Lambda$ & GABP \\
\hline .11110 & $\cdot / \cdot \vee \wedge \varepsilon$ & . I. fYG & . זr.|. & $\cdot / \cdot \Delta 99$ & $.1 .+48$ & MCGAP \\
\hline
\end{tabular}

(جدول - V): مقايسةٔ زمان اجراى برنامذٔ كاربردى توسط بخشبندى GABP در ده بار اجرا، با بخشبندى تطبيقى

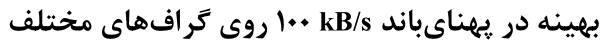

(Table-7): Comparison of Application Runtimes using GABP Partitioning for BW=100 kBps

\begin{tabular}{|c|c|c|c|c|c|c|}
\hline V. & q. & $\Delta$. & f. & r. & $r$. & \\
\hline $\mid f \Delta \wedge / \wedge \Delta \wedge q$ & IFGT/FTV & $1 \cdot \wedge \Delta / \wedge 9$ & ATI/TQAT & VYF/AqGQ & $\Delta F q / V q$ & توسط بخش زمان اجراى برنامه كابردى \\
\hline $\mid f \Delta V / \Delta q$ & $\mid f \Delta \Delta / \varsigma \varphi$ & $1 \cdot \wedge \& / 094$ & $\Lambda T M / \Lambda \Lambda \cdot r$ & VTY/TY & $\Delta F q / V q$ & زوسط بخش اجراى برنامهى كابردى \\
\hline
\end{tabular}

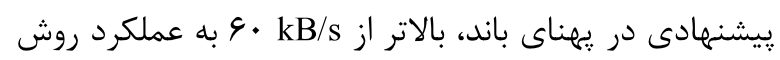

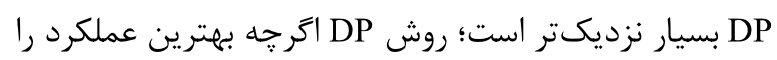

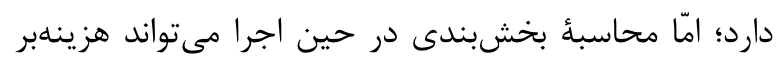

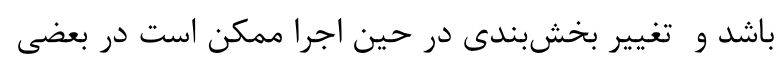

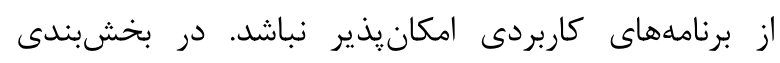

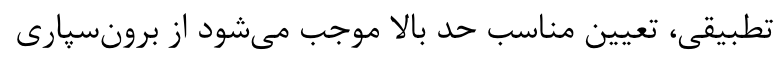

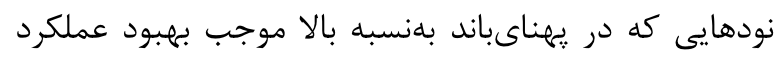

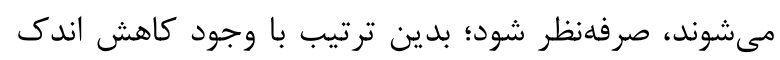

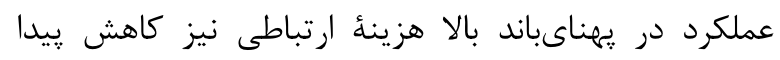

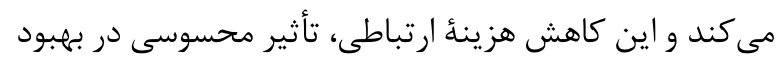

r-ه- ارزيابى كارايى روشهاى مختلف از نقطهنظر زمان اجرا و مصرف انرزى برنامه

\section{كاربردى}

در اين بخش كارايى روشهاى مختلف از نقطهنظر زمان اجرا

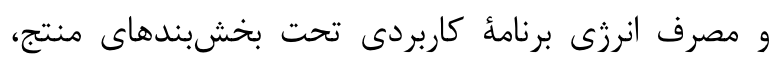

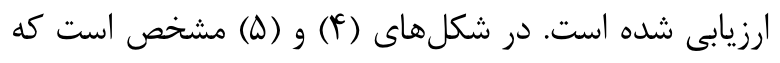

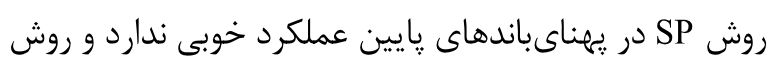

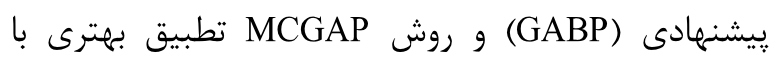

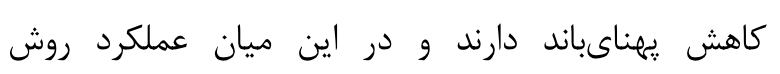


نسبت به بخشبندى محاسبهشده توسط الكوريتم (GABP)

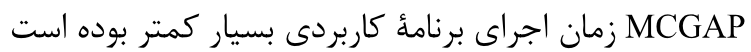
و اختلاف عملكرد دو الكوريتم نسبت به كَرافهاى قبلى بسيار محسوس است. اين مشاهده را مىتوان به اين شكل توجيه

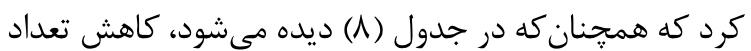
كرههاى تأثير كذار بوده و موجب افت كار ائى در ائ در اين الكوريته شده است. در الكَوريتم MCGAP كه الكوريتمى حريصانه است، تنها تعداد m تعداد كرهايى هستند كه بايد بخشبندى شوند) كه مبناى

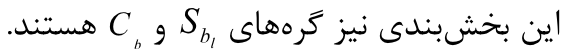

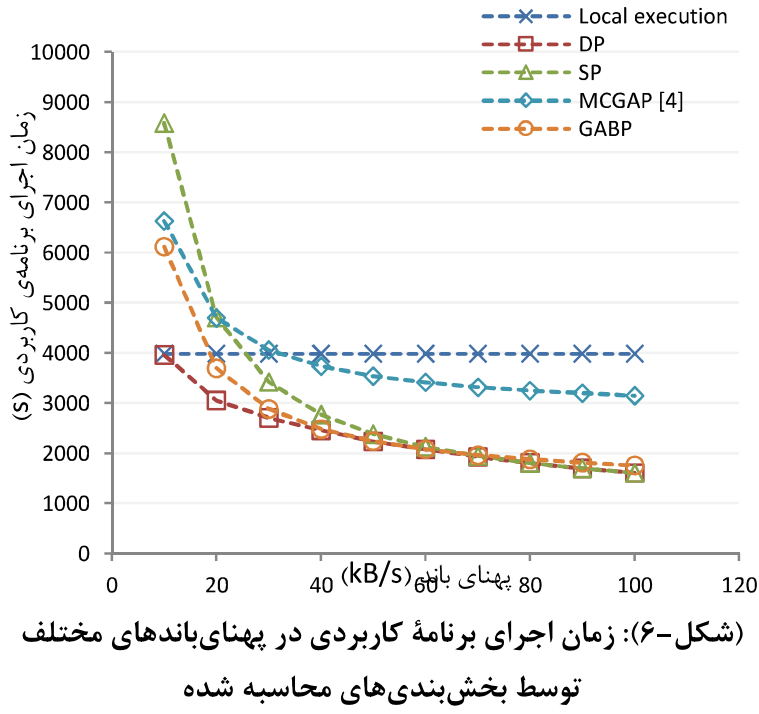

(Figure-6): Application Runtime using Partitioning

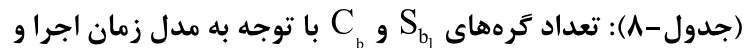
بر اساس ترافهاى تصادفى توليدشده

(Table-8): Number of $S_{b 1}$ and $C_{b}$ based on Random Graph Runtimes

\begin{tabular}{|c|c|c|c|}
\hline مجموع & C تعداد & $\begin{array}{c}S_{b_{1}} \\
\text { تعداد }\end{array}$ & نوع تراف \\
\hline 19 & r & 14 & كراف با • بـ حره \\
\hline ro & 1 & re & گراف با • ب كره \\
\hline rr & r & ri & كراف با • ه 0,0 \\
\hline r & 1 & $r$. & كراف با •ع كره \\
\hline$\mu \varphi$ & 1 & pr & گراف با · كره \\
\hline r & 1 & 1 & گراف با •^ گَره \\
\hline
\end{tabular}

در جدول (9) ديده مىشود كه با وجود تبادل داده

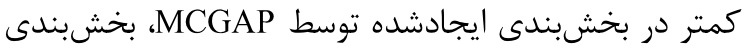

عملكرد در بيهناىباندهاى بايين دارد. با اين وجود جدولهاى

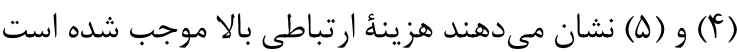
كه عملكرد Local execution (اجراى محلى برنامأ كاربردى الفى روى تلفن همراه بدون بخشبندى) بهتر از عملكرد بخشبندىهاى ايجادشده توسط روش ييشنهادى (GABP) و الكَوريتم MCGAP در يهناىباند kB/s • إباشد. بنابراين لازم است با درنظركرفتن محدوديت تبادل داده در بخشبندى، هزينهُ ارتباطى را بهتر كنترل كرد.

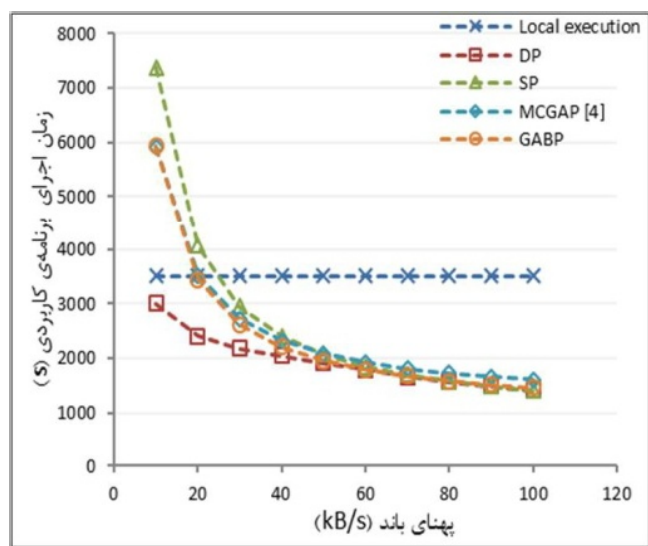

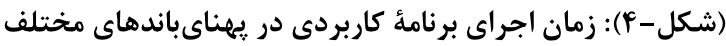

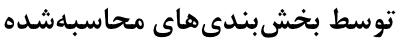

(Figure4): Application Runtime using Partitioning

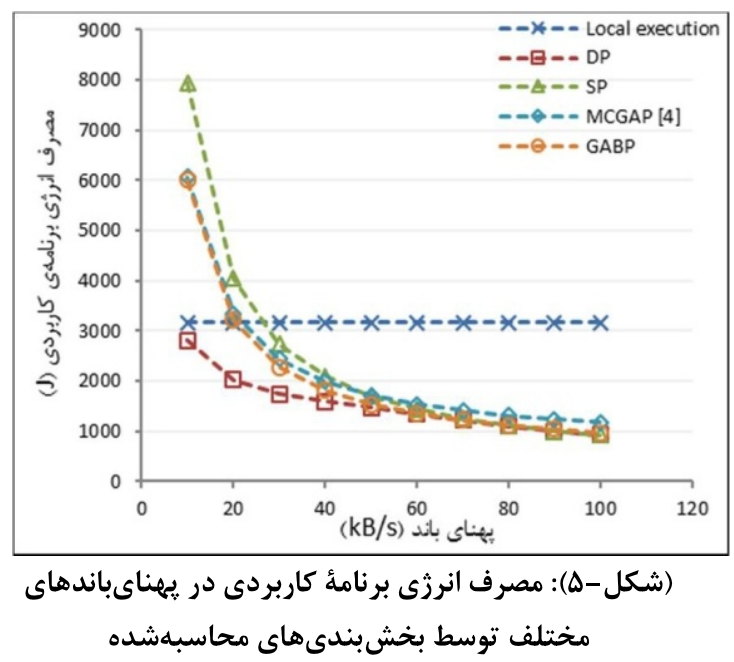

(Figure-5): Energy Consmuption of Application using Partitioning

تصادفى با •• رأس و ب•هORGs Random WORGs using 70 Nodes and 503 Links

در ادامه ارزيابى دقيقترى از عملكرد روش پِيشنهادى

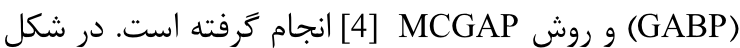
(9)، روى ₹َراف تصادفى توليدشده با هشتاد رأس و هفتصد يال، تحت بخشبندى محاسبهشده توسط روش پِيشنهادى 
در اين بخش تأثير خدمات وب و محدوديت تبادل داده بر بخشبندى تطبيقى در روش پيشنهادى

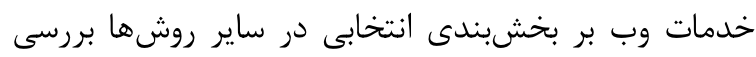

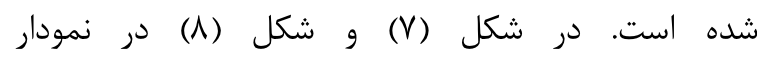
GABP(10000 KB)

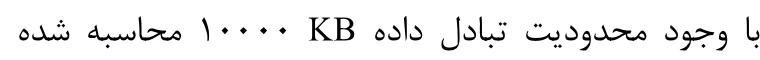

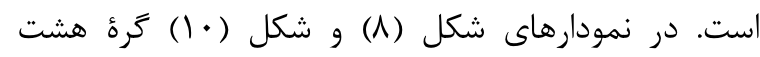
بهنوان خدمات وب در نظر ترفته شده است. مقايسٔ نمودار

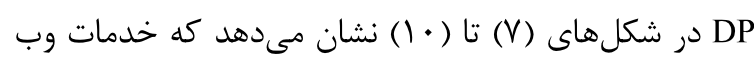

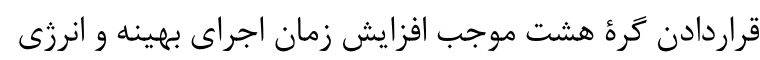

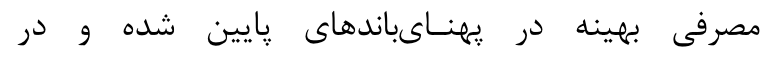
يهناى باندهاى بالا تغييرى ايجاد نكرده است.

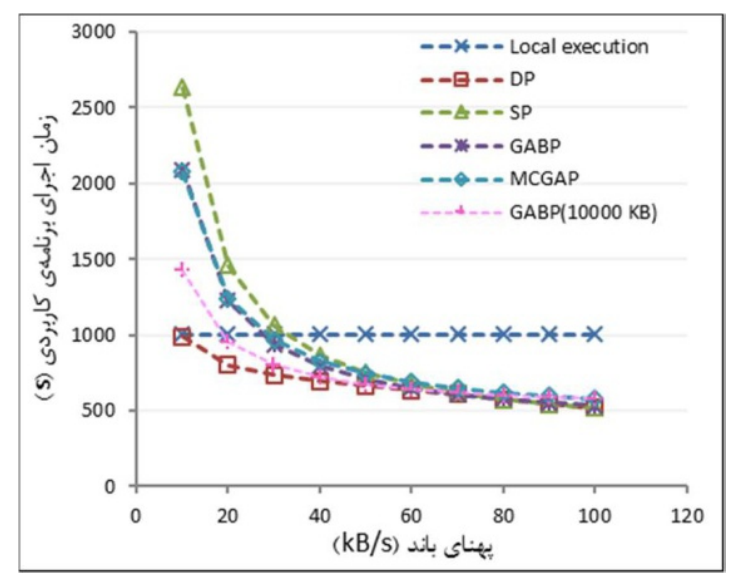

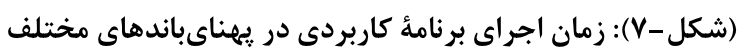

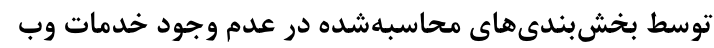
(Figure-7): Application Runtime Based on Partitioning for NoWeb Service Case

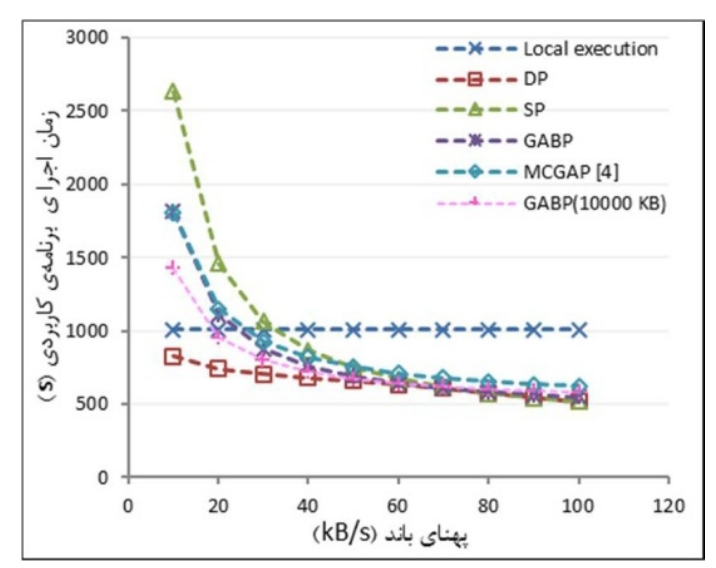

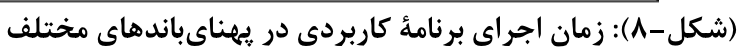
توسط بخشبندى هاى محاسبهشده با وجود خدمات وري

(Figure-8): Application Runtime Based on Partitioning for Web Service Case

تصادفى با • TORGs

Random WORGSs using 20 Nodes and 63 Links
محاسبهشده توسط روش پيشنهادى (GABP) در يهناىباند

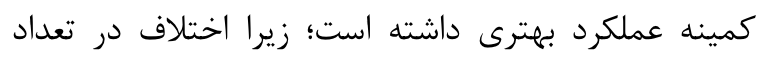
نودهاى برونسيارىشده و ميزان تبادل داده بهَّونهاى است

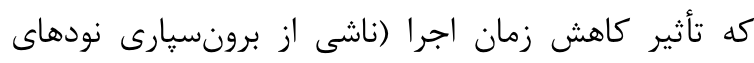

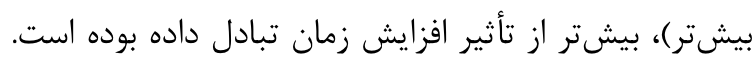

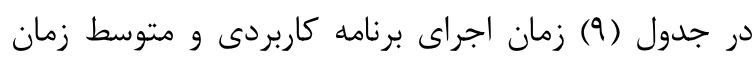

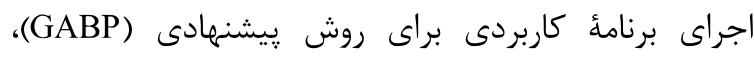

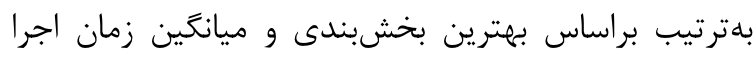

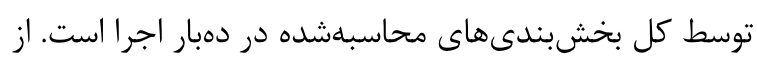

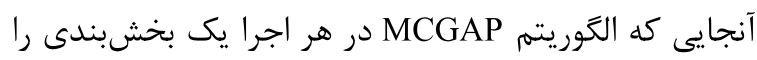

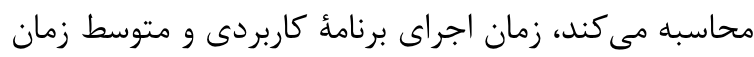

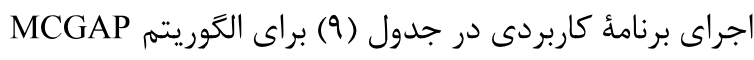
برابر است.

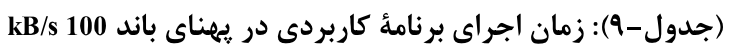

توسط بخشبندى هاى تطبيقى شكل (F)

(Table-9): Application Runtime for BW=100 kBps using Adaptive Partitioning in Figure (4)

\begin{tabular}{|c|c|c|c|c|}
\hline مبادله & 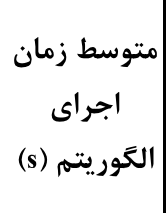 & 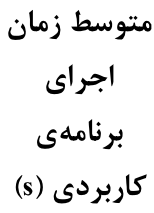 & 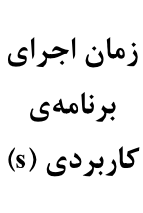 & الكوريتم \\
\hline 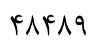 & $r / \Lambda 1 \cdot \Delta I V q \mu$ & $\mid \vee \wedge \Delta / r \Delta q$ & $1 V \Delta V / 99$ & GABP \\
\hline rASTV & س & r & r & MCGAP \\
\hline
\end{tabular}

همجنين جدول (• (1) نشان مى دهد كه در بخشبندى GABP

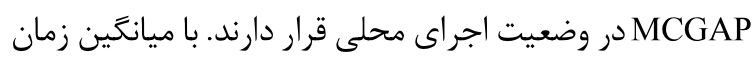

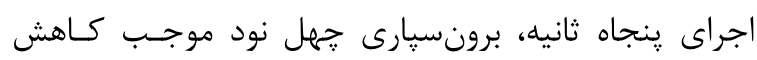

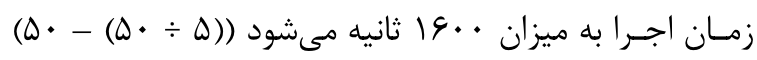

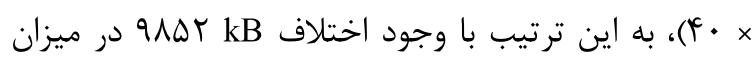

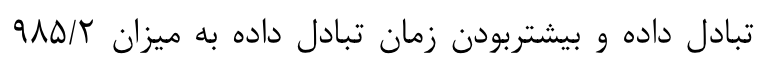

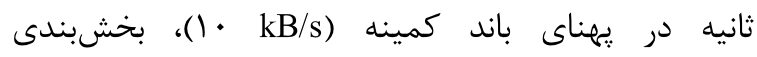

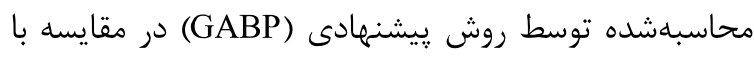

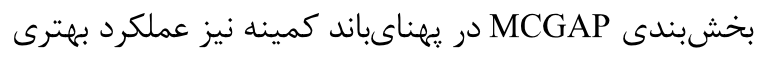
داشته است.

ץ-ه- بررسى تأثير خدمات وب و محدوديت

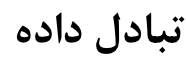




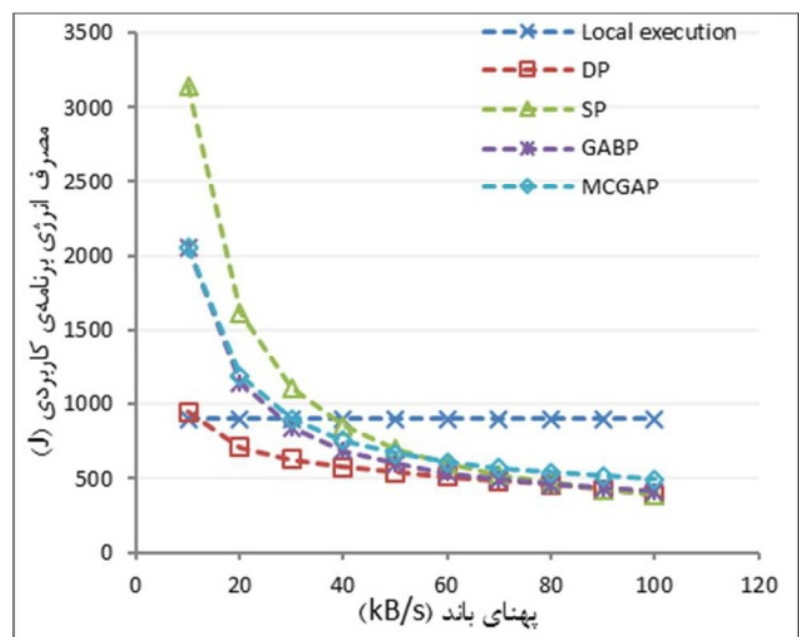

(شكل-•(1): مصرف انرزى برنامة كاربردى در يهناىباندهاى

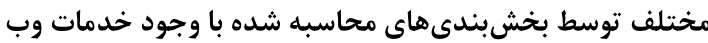
(Figure-10): Energy Consumption of Application Based on Partitioning for Web Service Case

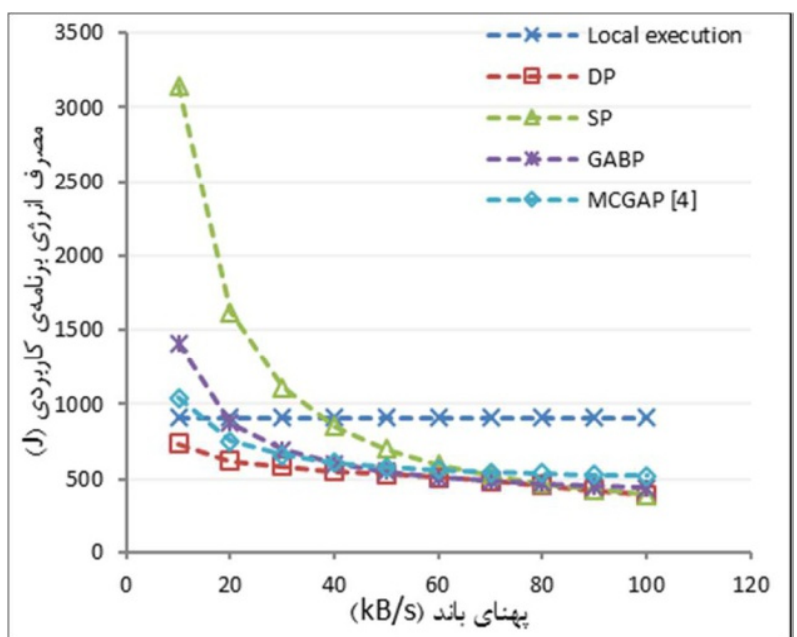

(شكل-9): مصرف انرزى برنامه كاربردى در يهناىباندهاى مختلف توسط بخشبندى ماى محاسبه شده در عدم وجود

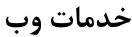

(Figure-9): Energy Consumption of Application Based on Partitioning for No-Web Service Case

WORGs

Random WORGs using 20 Nodes and 63 Links

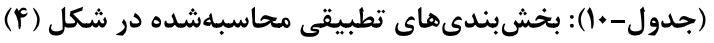

(Table-10): Adaptive Partitioning for Figure (4)

\begin{tabular}{|c|c|}
\hline بخشبندى & الكوريتهم \\
\hline 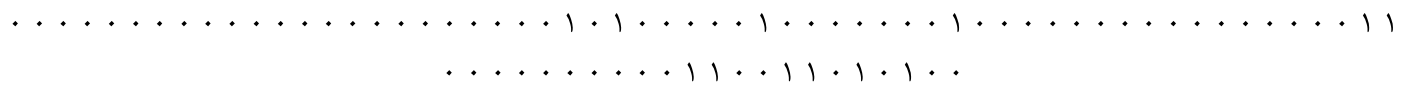 & GABP \\
\hline $\begin{array}{r}1 \cdot 111111 \cdot 1111111111,1 \cdot 11 \cdots 1 \cdots 11111 \cdots 1 \cdots 1 \cdots 11 \cdots 111111 \\
11 \cdots 1 \cdots 11 \cdot 1 \cdot 1 \cdot 111111 \cdot 1\end{array}$ & MCGAP \\
\hline
\end{tabular}

(جدول-1|): ميزان داده مبادلهشده توسط بخشبندىهاى محاسبهشده در شكل (V) و شكل (A)

(Table-11): Transferred Data using Claculated Partitioning Based on Figs 7 and 8

\begin{tabular}{|c|c|c|}
\hline وجود خدمات وب & عدم وجود خدمات وب & الكوريتم \\
\hline IVrqG & $\mid f \cdot r q$ & GABP \\
\hline THQYA & THQTA & SP \\
\hline 19910 & 14191 & MCGAP \\
\hline$q f i r$ & $q F \Delta \Lambda$ & GABP $(10000 \mathrm{~KB})$ \\
\hline
\end{tabular}

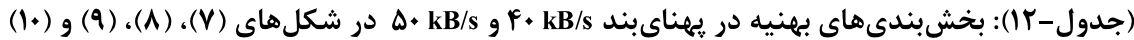
(Table-12): Optimized Partitioning for Different Bandwidths Based on Figs 7, 8, 9, and 10

\begin{tabular}{|c|c|c|c|c|}
\hline مقدار عددى & 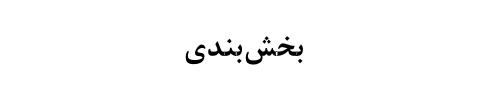 & وجود يا عدم وجود خدمات وب & يهناىباند & 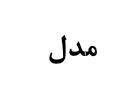 \\
\hline GAI/AVD & $\cdots 1 \cdots 11 \cdot 1 \cdot 11 \cdot 1111$ & عدم وجود وبسرويس & \multirow{2}{*}{ f. } & \multirow{2}{*}{ زمان اجرا } \\
\hline $99 \Delta / 4 \& q 1$ & $\cdots 1 \cdots 11 \cdot 1 \cdots 1 \cdots 111$ & وجود وبسرويس & & \\
\hline$\Delta r r / \Delta f / 9$ & $\cdots 1 \cdots 11 \cdot 1 \cdot 11 \cdot 1111$ & عدم وجود وبسرويس & \multirow{2}{*}{$\Delta \cdot$} & \multirow{2}{*}{ مصرف انرزى } \\
\hline$\Delta f I / \cdot G F$ & $\cdots 1, \cdots 11 \cdot 1 \cdot 1, \ldots+111$ & وجود وبسرويس & & \\
\hline
\end{tabular}




\section{Web API -}

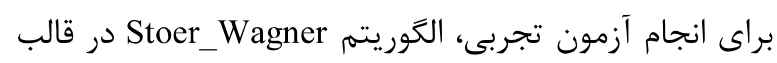

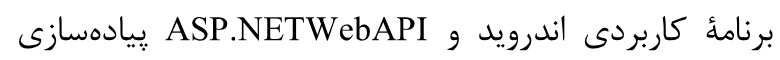
شده و بخشبندى در سطح تابع انجام كرفته است، توابع اندرون

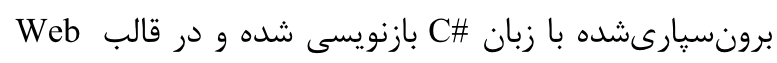

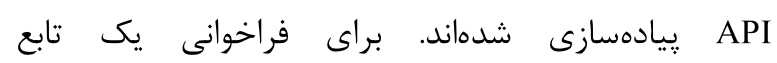

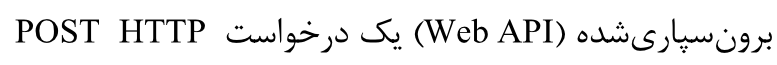
به سرور ارسال مىشود و نتايج نيز در قالب يك ئ ياسخ

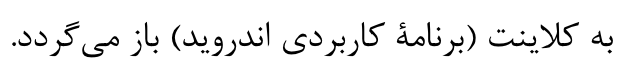

\section{- - - ن}

\section{برونسيارى يك برنامةٔ كاربردى اندرويد}

در آزمايش انجامشده برنامئ كاربردى اندرويد روى تلفن برامه

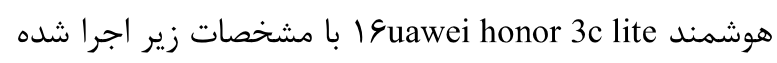

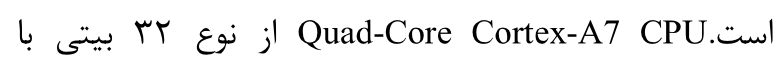

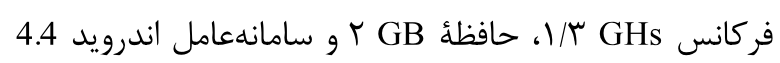

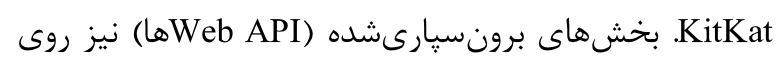

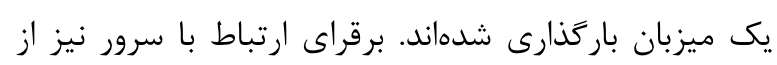

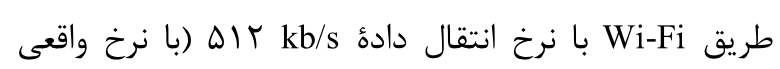

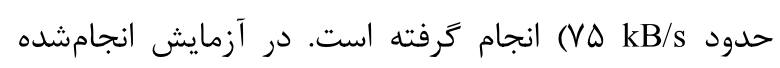

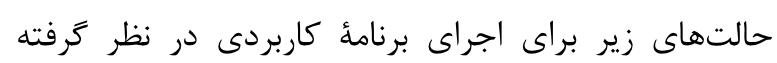

شدهاند:

•در آزمايش انجامشده حالتهاى زير براى اجراى برنامئ كاربردى در نظر گرفته شدهاند:

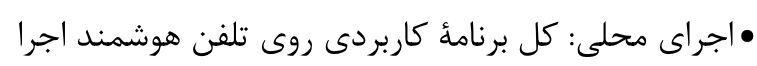

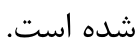

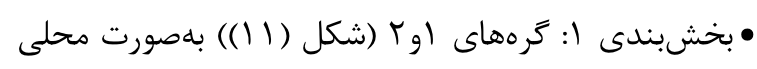

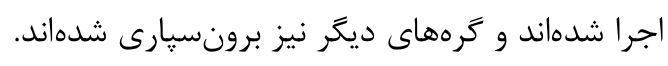

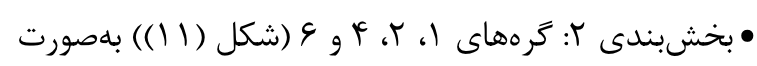

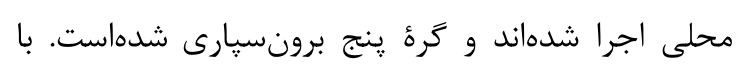

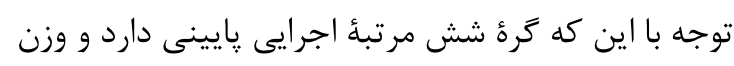

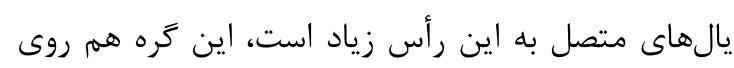

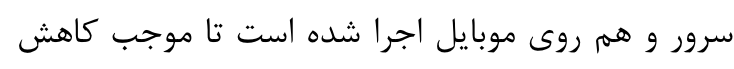

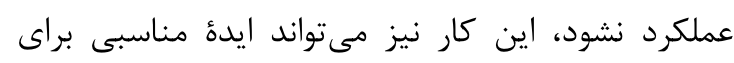

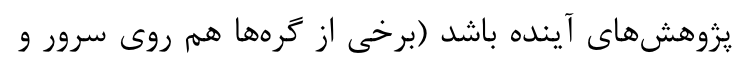
هم روى موبايل قابل اجرا باشند).

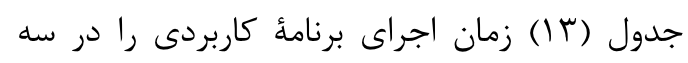

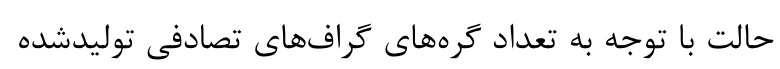

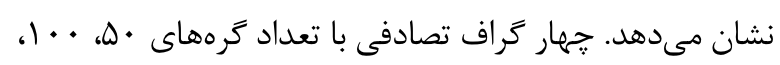

با افزايش زمان اجرا و انرزى مصرفى بهينه مقدار حد

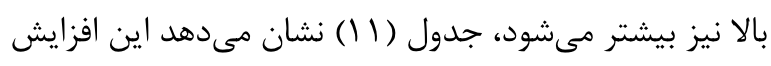

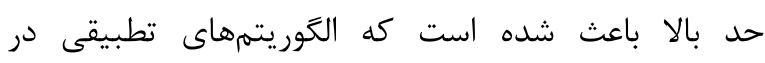

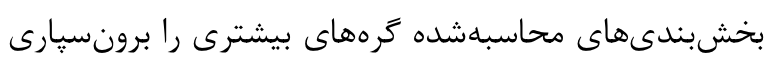

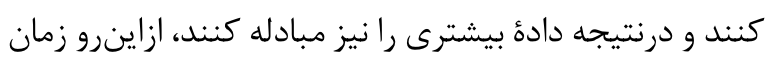

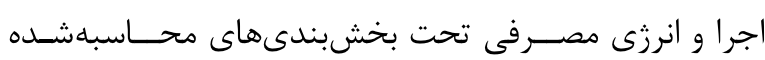

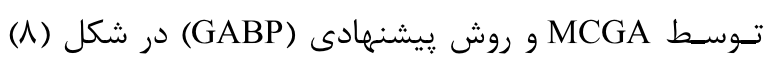

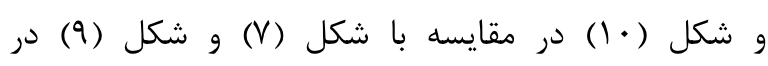

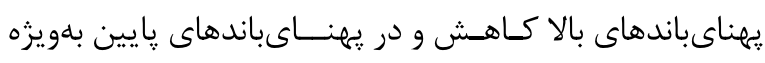

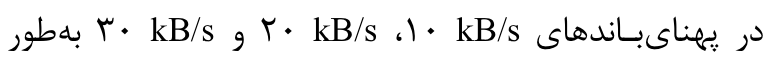

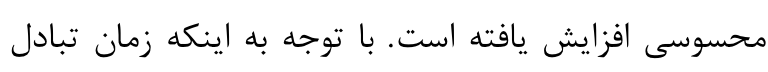

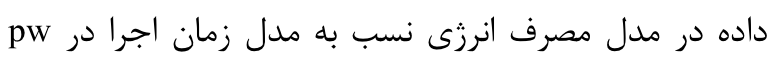

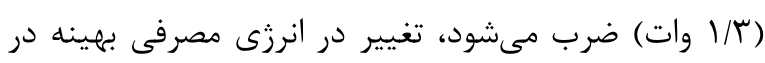
مقايسه با زمان اجراى بهينه بيشتر بوده است.

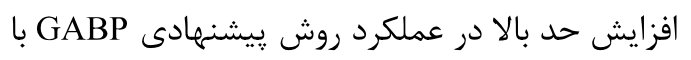

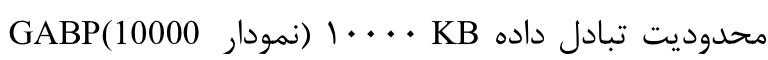

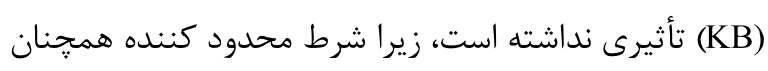

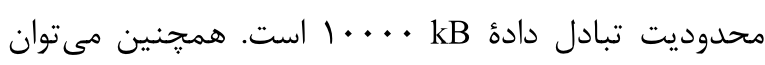
مشاهده كرد در روش بيشنهادى با تعيين محدوديت تبادل دادل مداد

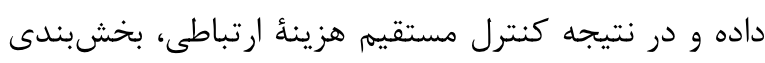
تطبيقى با عملكرد بهترى ايجاد شده است.

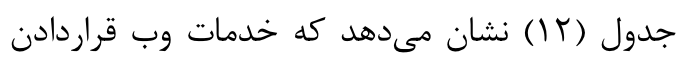

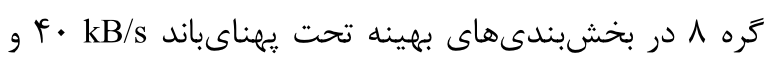

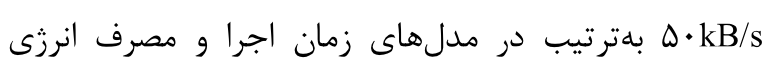

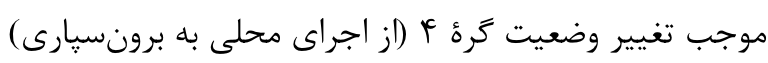

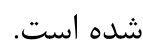

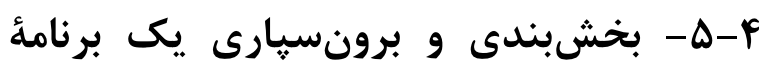 كاربردى اندرويد}

در اين بخش نحوء بخشبندى و برونسيارى الكَوريتم

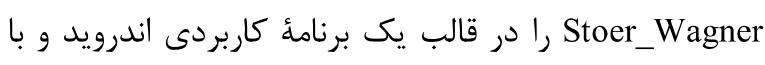
استفاده از ASP.NET Web API [17] تشريح شده است.

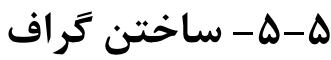

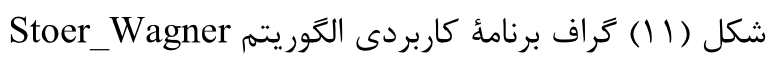

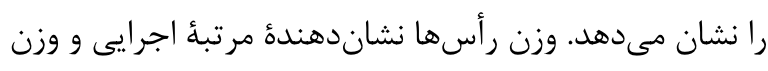

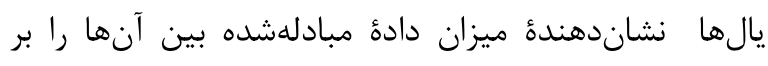
اساس n و بر حسب بايت است، كه n تعداد كرههاى كرافى است كه الكوريتم روى آن اجرا مى شود. 
موبايل و سرور بهطور جشم گيرى بالا بوده است. اين در حالى است كه با اجراى كره شش روى موبايل و سرور هزينهُ انتقال، كاهش داده شده است.

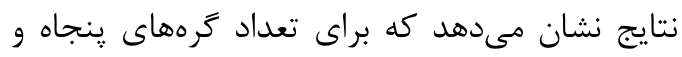

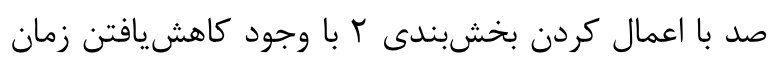
اجرا روى تلفن همراه، تأخير ايجادشده براى انتقادل داده و برقراى ارتباط با سرور قابل جبران نبوده، به همين علت اجراى برنامه كاربردى بهصورت محلى عملكرد بهترى داشته است.

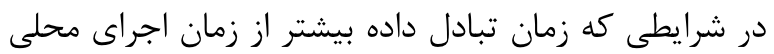
روى تلفن همراه است، برونسيارى اجرا، نمىتواند موجب بهبود عملكرد شود حتى اگر سرعت سرور بىنهايت باشد.

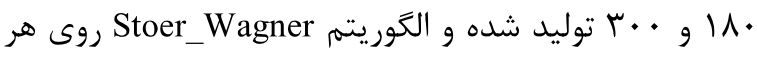
كراف و براى هر يك از سه حالت در نظرگرفته شده، ده بار اجرا شده است. متوسط زمان تبادل داده شامل زمان برقرارى : ارتباط نيز مىشود. نتايج نشان مىدهد كه اعمال بخشبندى

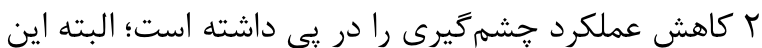
نتيجه قابل انتظار بود؛ زيرا اين بخشبندى در مجموع موجب رئ

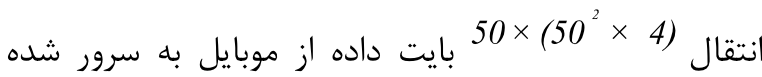

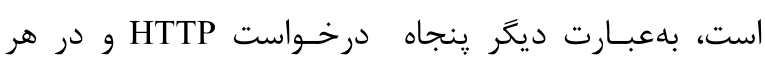

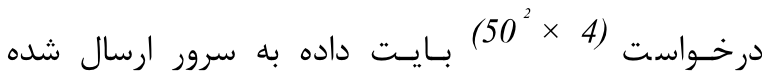

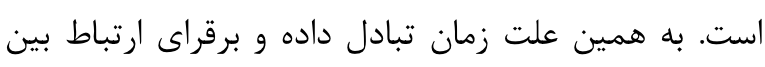

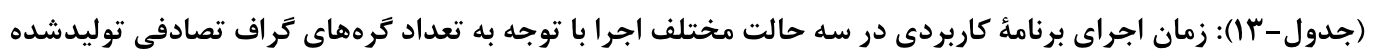

(Table-13): Application Runtime Based on Random Nodes Creation

\begin{tabular}{|c|c|c|c|c|c|}
\hline متوسط زمان اجراى & متوسط زمان اجرا & متوسط زمان & اجرا روى سرو زمان & حالت اجرا & تعره \\
\hline W.r. & $\cdot / 11 \cdot \Delta$ & .1911 & $\cdot / \cdot V \wedge$ & بخشبندى 1 & \multirow{3}{*}{$\Delta \cdot$} \\
\hline - ITFFF & - ITYFF & - & - & محلى & \\
\hline$F v / .1 F q$ & $r / r q \cdot \wedge$ & $F r / \Delta q r \wedge q$ & $\cdot|\cdot T| Y \mid$ & بخش بندى r & \\
\hline $1 / V \cdot G 4$ & $\cdot / r \Delta G \Lambda$ & I/rGArd & $\cdot / \cdot \Lambda \| r \Delta$ & بخشبندى 1 & \multirow{2}{*}{$1 \cdots$} \\
\hline $1 / .491$ & $1 / .491$ & - & - & محلى & \\
\hline$r / .99 \wedge \Delta$ & $\cdot / F \vee \wedge \varepsilon$ & $T / r q \cdot r l$ &.$/ r q .9 F$ & بخش بندى 1 & \multirow{2}{*}{10.} \\
\hline$r / \bullet १ ९$ & $\Gamma / \cdot \wedge 94$ & - & - & محلى & \\
\hline 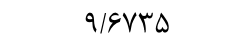 & $1 / \Delta T I T$ & D/AqFFA & r/rQVAT & بخشبندى 1 & \multirow{2}{*}{$\mu .}$. \\
\hline$r / / \Delta \Delta q F$ & $Y / / \Delta Q 9 Y$ & - & - & محلى & \\
\hline
\end{tabular}

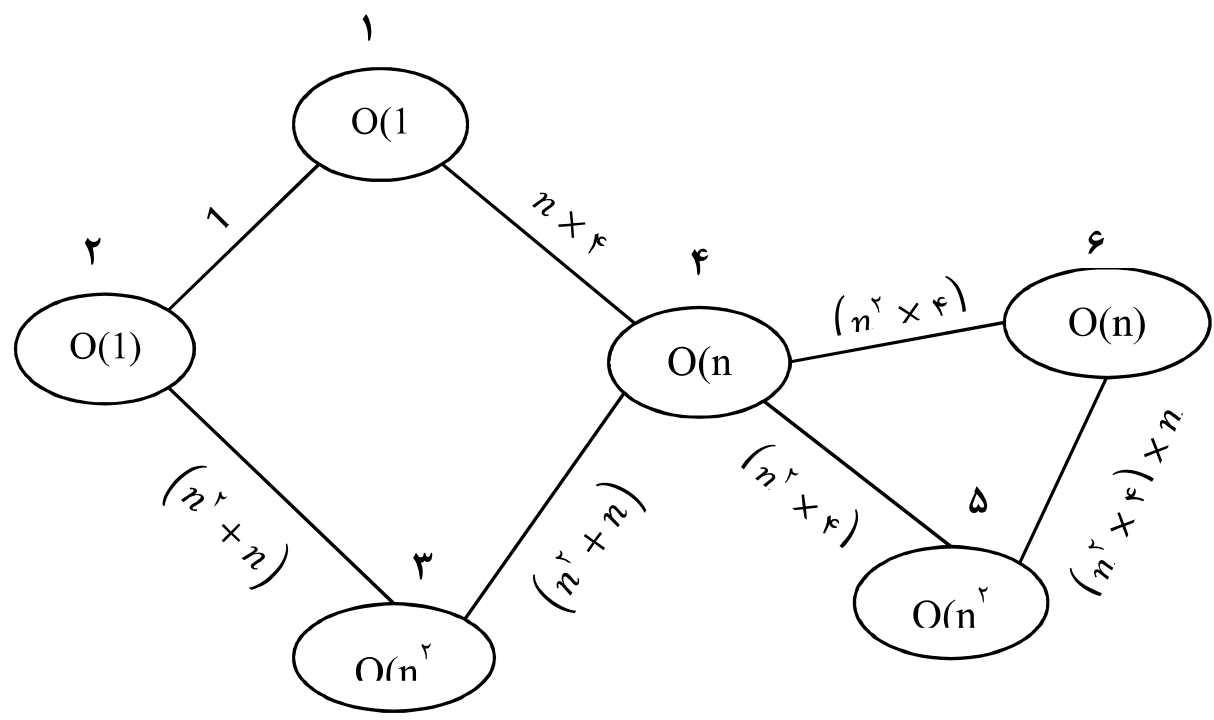

Stoer_Wagner شكل - (1): كراف برنامة الخوريتم

(Figure-11): Stoer_Wagner Algorithm Graph 
بخشبندى ا زمان اجراى الكوريتم Stoer_Wagner در كراف با سيصد گره نسبت به حالت اجراى محلى، حدود دوازده ثانيه كاهش يافته است. در شكل (IT) واسط كاربرى (UI) برنامة كاربردى ييادهازى شده براى بهدست آوردن بخشبندى بهينه

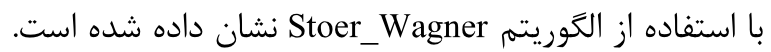

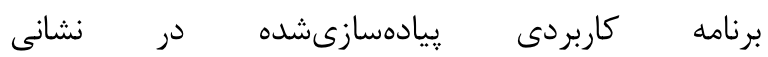

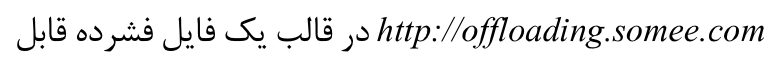
باركيرى است (كلمه عبور فايل فشرده: عץ).

\begin{tabular}{|c|c|}
\hline \multicolumn{2}{|c|}{ 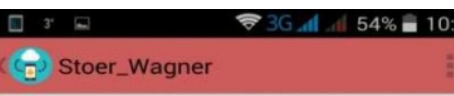 } \\
\hline \multicolumn{2}{|l|}{0} \\
\hline TLocal & Elocal \\
\hline 2477.0 & 2229.3 \\
\hline \multicolumn{2}{|c|}{ Weighted Value } \\
\hline \multicolumn{2}{|c|}{2477.0} \\
\hline \multicolumn{2}{|l|}{ Stoer_Wagner } \\
\hline \multicolumn{2}{|l|}{924.4} \\
\hline \multicolumn{2}{|c|}{ Response Times: } \\
\hline Partitioning 1: & $\begin{array}{l}0.0156(\mathrm{~S})+0.9144(\mathrm{C}) \\
+0.104(\mathrm{~L})=1.034 \mathrm{~s}\end{array}$ \\
\hline Local: & $0.232 \mathrm{~s}$ \\
\hline Partitioning 2: & $\begin{array}{l}0.0156(\mathrm{~S})+42.8234(\mathrm{C}) \\
+3.281(\mathrm{~L})=46.12 \mathrm{~s}\end{array}$ \\
\hline
\end{tabular}

نتايج نشان مىدهد كه با بزرگترشدن گراف و افزايش تعدا گرoها، زمان اجرا روى تلفن همراه نيز بيشتر شده و عملكرد اجراى محلى و بخشبندى ا نير بهتدريج به يكديگر

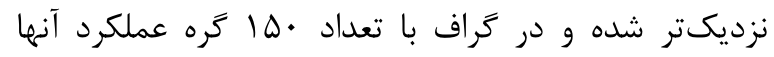
بهطورتقريبى يكسان بوده است. با افزايش تعداد گرمهاى كراف، ميزان داده مبادلهشده نيز بيشتر مى بـد؛ امّا نتايج نشان

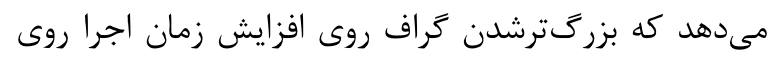
تلفن همراه تأثير بسيار بيشترى داشته، بهطورى كه با اعمال

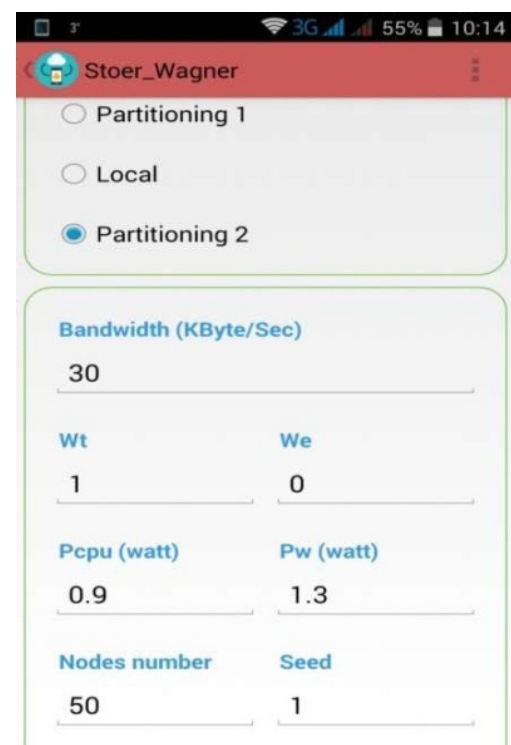

(شكل - I ): بيادهسازى الخوريتم Stoer_Wagner در اندرويد

(Figure-12): Android Implementation of Stoer_Wagner

خدمات وب در برنامههاى كاربردى و محدوديت تبادل داده ارائه شد و روشى مكاشفهاى مبتنى بر الكوريتم زنتيك نيز

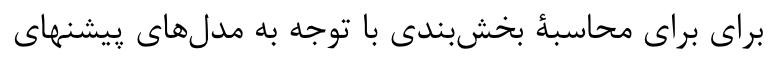

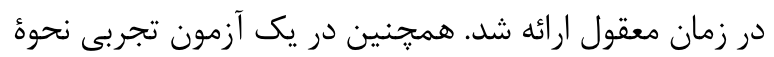

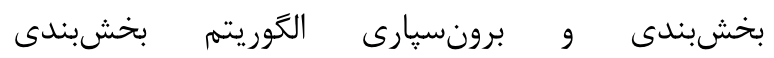

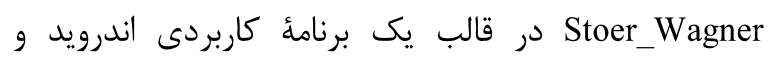
ASP.NET Web API نتايج شبيهسازى روى گرافهاى مختلف نشان داد كه الكوريتم ييشنهادى با توجه به زمان اجراى بسيار رايينتر

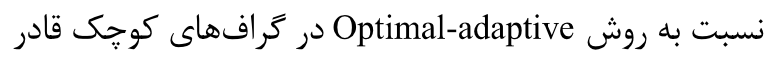
به يِيدا كردن بخشبندى بهينه است و در گرافهاى بزرگ نيز

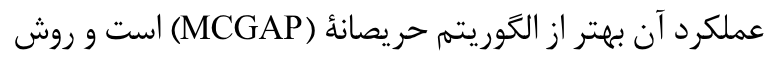
ييشنهادى تطبيق بهترى با تغييرات يهناىباند دارد (در بعضى آنى

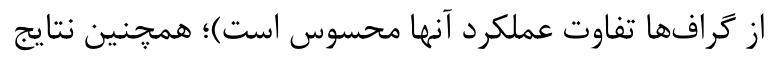
نشان داد كه استفاده از خدمات وب در برنامة كاربردى با

\section{9- نتيجه كيرى}

زمان اجراو انرزى مصرفى برنامههاى كاربردى و در قلب آنها،

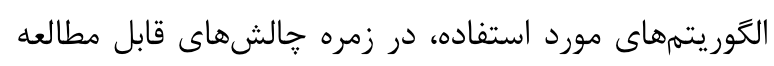

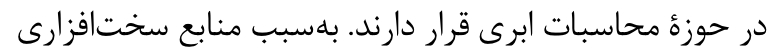
و نرمافزارى محدود، اين مورد بهصورت ويزه در تلفنهاى هوشمند و متعاقب آن محاسبات ابرى سيار نمود بيشترى ييدا كرده است. بهعنوان نمونهاى از الخوريتمهاى اشارهشده، به مانه

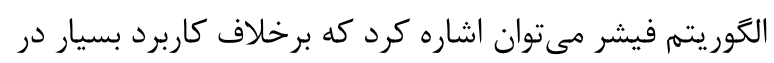
آشكارسازى سيگنال هاى صوتى و تصويرى زمان اجراى فئن بسيار بالايى را تحميل برنامه مى كند و راهحل هاى متعددى از جمله وله

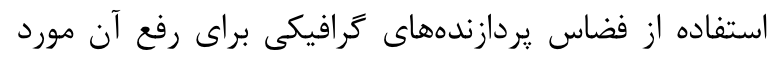

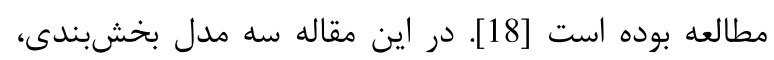
مدل بهينهسازى زمان اجرا، مدل بهينهسازى مصرف انرزى و

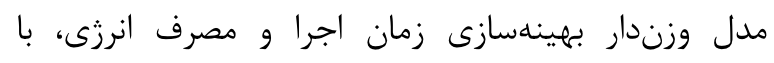
درنظرگرفتن تغييرات يهناىباند در تلفن هوشمند، استفاده از زمان 
smartphones in mobile cloud computing", Information Systems Frontiers, vol. 16(1), pp. 95111. 2014

[9] M.H. Tandel and V.S. Venkitachalam, "Cloud Computing in Smartphone: Is offloading a betterbet?", CS837-F12-MW-04A Wichita State University, 2013.

[10] T.Verbelen and et al, "Graph partitioning algorithms for optimizing software deployment in mobile cloud computing", Future Generation Computer Systems, vol. 29(2), pp. 451-459. 2013.

[11] E.Cuervo and et al, "MAUI: making smartphones last longer with code offload", in Proceedings of the 8th international conference on Mobile systems, applications, and services. ACM, 2010.

[12] Y.Zhang and et al, "Refactoring android java code for on-demand computation offloading", in ACM SIGPLAN Notices .ACM, 2012.

[13] R.Kemp and et al, "Cuckoo: a computation offloading framework for smartphones", in Mobile Computing, Applications, and Services, Springer, pp. 59-79, 2012.

[14] D.Kovachev, T. Yu, and R. Klamma, "Adaptive computation offloading from mobile devices into the cloud", in Parallel and Distributed Processing with Applications (ISPA), IEEE 10th International Symposium on, 2012.

[15] X.Wei and et al, "MVR: An Architecture for Computation Offloading in Mobile Edge Computing", in Edge Computing (EDGE), IEEE International Conference on. 2017.

[16]http://developer.android.com/guide/components/s ervices.html ( last accessed 12 Apr 2016).

[17]https://msdn.microsoft.com/enus/library/dd20305 2.aspx.

[18] h.sadeghi and A. Akhavan Bitaghsir, "Signal Detection Based on GPU-Assisted Parallel Processing for Infrastructure-based Acoustical Sensor Networks", Signal and Data Processing, vol.14(4), p p. 19-30. 2018.

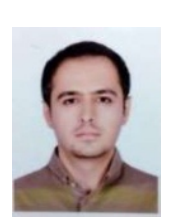

$$
\text { سياوش زاهدى فارغالتحصيل دوره كارشناسى }
$$$$
\text { ارشد رشته مهندسى فناورى اطلاعات از }
$$$$
\text { دانشخاه صنعتى اروميه است. حوزه تخصصى وى رئى }
$$$$
\text { بخشبندى يرداش و برون سيارى محاسبات در إنه }
$$

محيطهاى ابرى است. ايشان همجنين در حرون حوزه توسعه برنامههاى كاربردى مبتنى بر ويندوز، وب (asp.net mvc) و

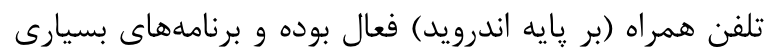
توليد كرده است. syavash.36@gmail.com

$$
\text { نشانى رايانامه ايشان عبارت است ازئ }
$$

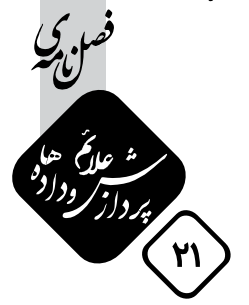

$$
\begin{aligned}
& \text { افزايش ميزان تبادل داده، مىتواند موجب تغيير در } \\
& \text { بخشبندى بهينه در يكى يهناىباند مشخص و و تغيير } \\
& \text { بخشبندى تطبيقى با يهناىباند شود كه با تعيين محدوديت }
\end{aligned}
$$

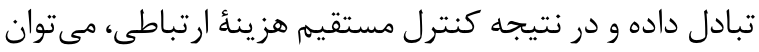

$$
\begin{aligned}
& \text { بخشبندى تطبيقى را با عملكردى بهتر ايجاد كرد. }
\end{aligned}
$$

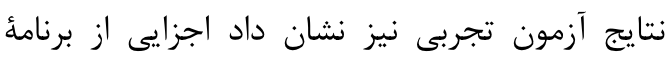

$$
\begin{aligned}
& \text { كاربردى كه نيازمند محاسبات زياد و تبادل داده كمى هستند، } \\
& \text { قابليت بيشترى براى برونسيارى دارند. همجنين در در آزمون } \\
& \text { تجربى انجامشده، مشاهده شد كه با زيادشدن محاسبات در بر برديس } \\
& \text { تلفن هوشمند، اختلاف زمان اجراى برنامئ كاربردى، در حالت الت } \\
& \text { اجراى محلى و اجرا روى سرور بيشتر مىشودا هون. }
\end{aligned}
$$

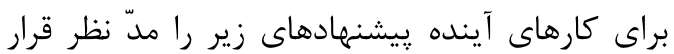

$$
\begin{aligned}
& \text { دادهايم. بخشبندى يك برنامة كاربردى اندرويد با استفاده از }
\end{aligned}
$$

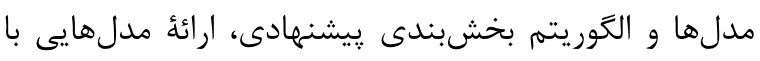

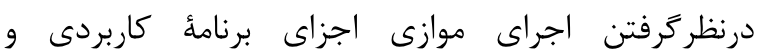

$$
\begin{aligned}
& \text { درنظر رَفتن حالتى كه ياسخ بخش برونسيارىشده به تلفن }
\end{aligned}
$$

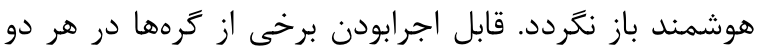

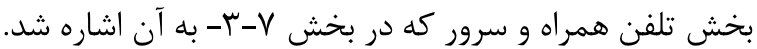

\section{7- References}

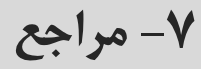

[1] K.Kumar and et al., "A survey of computation offloading for mobile systems", Mobile Networks and Applications, vol. 18(1), p p. 129-140, 2013.

[2] X.Ma and et al., "When mobile terminals meet the cloud: computation offloading as the bridge", IEEE Network, vol. 27(5), pp. 28-33, 2013.

[3] A.R.Khan and et al., "A survey of mobile cloud computing application models", Communications Surveys \& Tutorials, IEEE, vol. 16(1), pp. 393413, 2014.

[4] J.Niu, W. Song, and M. Atiquzzaman, "Bandwidth-adaptive partitioning for distributed execution optimization of mobile applications", Journal of Network and Computer Applications, vol.37, pp. 334-347. 2014.

[5] K.Kumar and Y.-H. Lu, "Cloud computing for mobile users: Can offloading computation save energy?" Computer,vol. 43(4), pp. 51-56. 2010.

[6] B.-G.Chun and et al, "Clonecloud: elastic execution between mobile device and cloud", in Proceedings of the sixth conference on Computer systems, ACM, 2011.

[7] P. Di Lorenzo, S. Barbarossa, and S. Sardellitti, "Joint Optimization of Radio Resources and Code Partitioning in Mobile Cloud Computing", arXiv preprint arXiv:1307, 2013, pp3835.

[8] F.Xia and et al, "Phone2Cloud: Exploiting computation offloading for energy saving on 


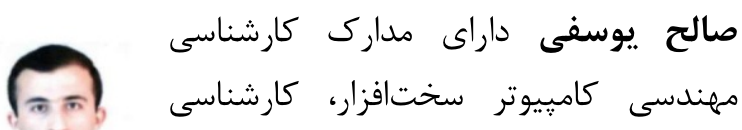

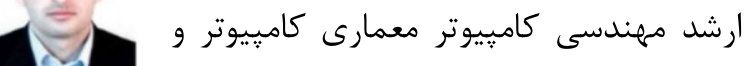
دكتراى ههندسى كامييوتر شبكههاى

كامِيوترى، هر سه از دانشَاه علم و صنعت ايران و دان در حال

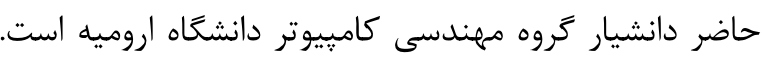
حوزهاى تخصصى ايشان شامل سامانهاى مخابراتى

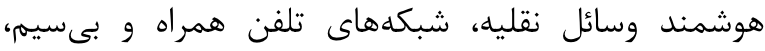
محاسبات ابرى، و مدلهاى اقتصادى در شبكهها است.

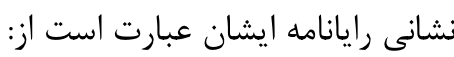
youssefi@cc.iut.ac.ir

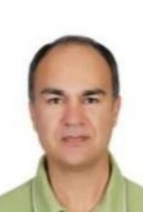
وحيد سلوك استاديار و مدير گروه مهندسى إنى

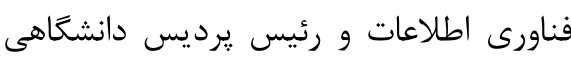

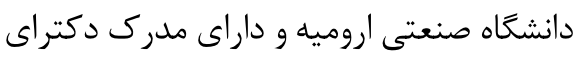

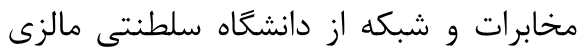 است. حوزه تخصصى ايشان شامل مديريت حركت، تخصيص منابع و كدكذارى شبكههاى بيسيمر و تلفن همراه و شبكههاى تلفن همراه نامتنجانس، محاسبات ابرى تلفن همراه، كيفيت سرويس و كيفيت تجربه در شبكههاى سلولى، و بهينهسازى

$$
\begin{aligned}
& \text { مصرف انرزى در شبكههاى بىسيم است. } \\
& \text { نشانى رايانامه ايشان عبارت است ازئ }
\end{aligned}
$$
v.solouk@it.uut.ac.ir 